Ankara Üniversitesi Ĕgitim Bilimleri Fakültesi Dergisi

Yll: 2020, Cilt: 53, Sayl: 1, 117-156

DOI: 10.30964/auebfd.582502, E-ISSN: 2458-8342, P-ISSN: 1301-3718

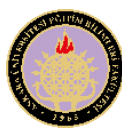

\title{
Akademik Başarı, Lisansüstü Eğitim Farkındalığı ve Lisansüstü Eğitim Niyeti Arasındaki İlişkiler ${ }^{1}$
}

\begin{tabular}{lccc}
\hline MAKALE TÜRÜ & Başvuru Tarihi & Kabul Tarihi & Yayın Tarihi \\
Araştırma Makalesi & 26.06 .2019 & 27.03 .2020 & 01.04 .2020 \\
\hline
\end{tabular}

İlhan İlter

Kahramanmaraş Sütçü İmam Üniversitesi

Öz

$\mathrm{Bu}$ araştırmada, lisans akademik başarı ortalaması ile lisansüstü eğitim niyeti arasındaki ilişkide lisansüstü eğitime ilişkin farkındalığın aracılık rolü incelenmiştir. Ayrıca araştırmada akademik başarı ve lisansüstü eğitime ilişkin farkındalığın lisans sonrası lisansüstü eğitim niyetini yordayıp yordamadığı test edilmiştir. Bu amaç kapsamında araştırmada öncelikle geçerlik ve güvenirlik çalışmaları yapılarak "Lisansüstü Eğitim Farkındalığı" ve "Lisansüstü Eğitim Niyeti” ölçme araçları geliștirilmiștir. Araștırmanın katılımcılarını bir devlet üniversitesinin eğitim fakültesinde farklı sınıf ve programlarda öğrenim gören 415 öğrenci oluşturmaktadır. Elde edilen verilerin çözümlenmesinde açımlayıcı faktör analizi, doğrulayıcı faktör analizi, korelasyon analizi ve yapısal eşitlik modellemesi (YEM) kullanılmıştır. YEM Analizi sonuçları, akademik başarının lisansüstü eğitim farkındalığını ve lisansüstü eğitim niyetini doğrudan yordadığını göstermiştir. Bulgular incelendiğinde akademik başarı ile lisansüstü eğitim niyeti arasındaki ilişkide lisansüstü eğitim farkındalığının aracılık rolü oynadığı görülmüştür. Araştırmada elde edilen bulgular iki bağlamda önemlidir. Birincisi, üniversite öğrencilerinin akademik başarısı ve lisansüstü eğitimle ilgili farkındalık düzeyleri lisansüstü eğitim niyetlerini yordamada önemli bir role sahiptir. İkincisi, lisansüstü eğitim farkındalığının üniversite öğrencilerinin lisans sonrası lisansüstü eğitime başlama niyetlerini öngörmede kilit nokta olabileceği görülmüştür. Bu anlamda lisansüstü eğitime ilişkin farkındalık gelişimi için üniversitelerin lisans öğrencilerine yönelik lisansüstü programların tanıtıldığı çalıştaylar yapması ve lisans sonrası eğitim olanakları hakkında danışmanlık hizmeti vermesi öğrencilerin var olan koşullarını erkenden iyileştirmelerine ve gelecekteki kariyer hedeflerine ilişkin düşünce yapılarını olumlu yönde şekillendirmelerine katkı sağlayabilir.

Anahtar sözcükler: Lisansüstü eğitim, kariyer gelişimi, akademik başarı, yapısal eşitlik modellemesi, bootstrapping yöntemi.

${ }^{1} \mathrm{Bu}$ çalışmadaki verilerin bir bölümü 8. Uluslararası Sosya Bilgiler Eğitimi Sempozyumu'nda sunulmuş̧ur. ${ }^{2}$ Sorumlu Yazar: Doç. Dr., Eğitim Fakültesi, Türkçe ve Sosyal Bilimler Eğitimi Bölümü, Sosyal Bilgiler Eğitimi Anabilim Dalı, E-posta:iilter@ksu.edu.tr, https://orcid.org/0000-0002-4411-200X 


\section{Lisansüstü Eğitim ve Önemi}

Bir ülkenin bilim ve teknoloji yeteneğinin yükseltilmesi ve bunu sağlayacak nitelikli insangücünün yetiştirilmesinde kuşkusuz yükseköğretimin rolü büyüktür. Yükseköğretim, araştırma ve geliştirme etkinlikleri aracılığıyla eğitim, dil, kültür, sanat, sağlık ve ekonomi alanında kalkınmada ayrıca bilim ve teknoloji anlamında ilerleme kaydedilmesinde lokomotif görevi üstlenebilmektedir (Tosun, 2001; Ünal ve İlter, 2010). Yükseköğretim, yüksek nitelikte öğretim hizmeti sunmak, küresel sorunları doğru algılamak, bu sorunlara akılcı çözüm önerileri sunmak, bilimsel araştırmalar yürütmek ve kalkınma için yüksek düzeyli insangücünü yetiştirmek gibi çeşitli işlevlere sahiptir (Karakütük, 2000; Sevinç, 2001). Nitekim bir üniversitenin saygınlığı sağladığı eğitim ve kariyer olanakları yoluyla öğrencilerini en iyi biçimde eğitebilme ve geleceğe güvenle hazırlayabilme gücüne bağlıdır.

2547 Sayılı Yükseköğretim Kanununda belirtildiği gibi, yükseköğretim kurumlarının önemli göstergelerinden biri de yüksek lisans, doktora veya sanatta yeterlik programlarını kapsayan lisansüstü eğitim ve öğretim faaliyetidir (Yükseköğretim Kurulu, YÖK, 2016). Lisansüstü eğitim, bireylerin kariyer hedeflerini gerçekleştirdiği, bilimsel etkinlik ve araştırma çalışmalarını deneyimlediği bir öğretim sürecidir. Başka bir deyişle, lisansüstü eğitim bireylerin uzmanlık alanına özgü akademik deneyim çeşitliliğini geliştirmeye, bir akademik çevreye ve araştırma sahasına dahil olmaya ya da kariyer yolunda ilerlemeye olanak sağlayan bir örgün öğretim etkinliğidir (Artess ve Hooley, 2017; Cragg ve Andrusyszyn, 2004; Karakul ve Karakütük, 2014).

Lisansüstü eğitimin amacı, bir alanda uzmanlaşmak için entelektüel becerilerin gelişimini ve devamını sürdürmek, profesyonel yetkinlik ve akademik değerler geliştirmektir. $\mathrm{Bu}$ eğitimin bilim kariyeri ve meslek yaşamı için yüksek nitelikli eğitim verme konusunda bireysel entelektüel ve kültürel zenginliği sağlama, yaşam boyu öğrenme gibi çeşitli amaçları bulunmaktadır (Aitken, Currey, Marshall ve Elliott, 2008; Karakütük, 2009). Battie ve Steelman (2014), lisansüstü eğitimin belirli bir alanda bilgi ve teknik beceriler hakkında yüksek bir yetkinlik kazanmaya, profesyonel gelişim sağlamaya ve hesap verebilirlik çerçevesinde profesyonel standartları başarmaya yardımcı olduğunu belirtmiştir. Bu bakımdan lisansüstü eğitim, belli bir alanda yetişmeyi ve uzmanlaşmayı amaçladığı için lisans düzeyinde elde edilen yeterliklerden ayrilmaktadır (Gradschools com., 2019; İlter, 2019). Araştırmalar, lisansüstü eğitimin bireylerin kişisel ilişkilerini, akademik ve sosyal yaşamlarını önemli ölçüde değiştirdiğini ve uzmanlıklarını artırdığını göstermiştir (Chaboyer ve Retsas, 1996; Ng, 2016).

Bugün, lisansüstü eğitim her ne kadar zorunlu olmasa da lisans derecesini elde eden bireyler için hangi mesleği yürütecek olursa olsun lisansüstü öğrenim görmek iş ve kariyer gelişimi için temel bir gereksinim olmuştur. Çünkü lisansüstü eğitim, bireylerin kariyer gelişimini geçekleştirebilecekleri en iyi alanlardan biri olduğu gibi, bu eğitim sürecinde kazanılan yeterlikler kariyer gelişiminin birçok yönünü bir araya getiren zengin bir tema olmaktadır (Artess ve Hooley, 2017; Johnson ve Copnell, 
2002; Neumann, 2003; Ohnishi ve Ford, 2015). Araştırmacılar lisansüstü deneyimlerin bireylere işgücü piyasasında açık bir üstünlük sunması ve bir alanda uzman kimliği kazandırması nedeniyle bu eğitim olanaklarının her geçen gün kariyer yükselmesi açısından kaçınılmaz duruma geldiğini vurgulamıştır (Purcell ve diğ., 2012; Varhegyi ve Jepsen, 2009a). Dolayısıyla lisansüstü düzeyde öğrenim, yeni ve yaratıcı yollarla bilgi derinliğini artırmak ve ileri düzeyde araştırma yeterliklerine sahip olmak için akademik ve bilimsel yaklaşımlarla yapılandırılan bir kariyer kimliğini oluşturma olanağıdır (İlter, 2019; Lindley ve Machin, 2013; Wakeling, 2009).

\section{Kariyer Gelişiminde Lisansüstü Eğitim}

Yükseköğretim süreci, bireylerin gelecekteki kariyerlerine yönelik önemli kararlar aldığ 1 kritik bir dönemdir (Wisker, 2007). Kariyer eğitim ve iş olanaklarını izleme, kendini daha iyi tanımlama, iş dünyası hakkında bilgi edinme, kariyer planları yapabilme ve başarı veya performans (edim) için destek arama ya da yaşam rollerini dengelemeyi içeren bir kavram olarak görülmektedir (Briscoe, 2002; Stewart ve Knowles, 1999). Kariyer gelişimi, yaşam boyu devam edecek bir içsel süreç olarak kavramsallaştırıldığından gençlerin gerçek iş ortamını deneyimlemeden önce kendi kariyerleri hakkında düşünmeye başlamaları oldukça önemlidir (Hartung, Porfeli ve Vondracek, 2008).

Kariyer planlamaya ilişkin alınan kararlar, bireylerin akademik ve mesleki rol ve statüsünü, psikolojik durumunu, sosyal kabulünü ve yaşam boyu öğrenme niteliğini etkileyebilmektedir (Gati, Krausz ve Osipow, 1996; Mann, Harmoni ve Power, 1989). Araştırmacılar kariyer gelişimine yatırım yapmada özellikle lisansüstü deneyimlerin güdüleyici bir etken olduğuna dikkat çekmiştir (Leman, 2015; Stuart, Lido, Morgan, Solomon ve Akroyd, 2008). Örneğin yüksek lisans derecesi, erken kariyer dönemi için üniversite öğrencileri tarafından çoğunlukla başvurulan bir yoldur (Buchanan, Kim ve Basham, 2007; Gardner ve Barnes, 2007; Nas, Peyman ve Arat, 2016). Bragt, Bakx, Teune, Bergen ve Croon (2011) yüksek lisans eğitimi ile kariyer veya iş yaşamına adım atan bireylerin gelecekte kendilerinin akademik bağlamda farkındalık düzeylerini artırdığını, profesyonel bağlamda ise sürekli mesleki gelişim göstermelerini güçlendirdiğini savunmuştur.

Lisans sonrası bir lisansüstü programa başlama kararı, aslında mesleki gelişim, akademik kariyer niyeti veya iş dünyasına hazırlanmak (Ör. İnisiyatif alma ve girişimcilik) ile ilişkilidir. Kariyer amaçlarının belirlenmesi ile ilgili bir karar, yüksek lisans veya doktora gibi bir lisansüstü programa katılıp katılmama kararı ile bağdaştırılabilir. Kariyer kararını bu nedenle lisansüstü eğitim alma kararına uygulamak oldukça uygundur (Varhegyi, 2009). Araştırmalar, lisansüstü eğitim yeterliğini sağlamış bireylerin araştırma deneyimlerine dayanarak meslek yaşamlarında önemli kararlar alabildiğini, etkili yöntemler kullandığını, mesleğe katkılar konusunda kendilerine daha fazla güven duyduğunu ve meslektaşlarına rol model olduğunu ortaya koymuştur (Cotterill-Walker, 2012; Pelletier, Donoghue ve Duffield, 2003). Bu bakımdan öğrencileri lisansüstü eğitim almaya yönlendirmek, 
onların gelecekteki iş ve kariyer yaşamları açısından stratejik bir adım olarak değerlendirilmektedir (Kerry, 2012; Watson ve Stead, 1997).

Kariyer kararı, henüz lisans öğrenimi aşamasında olan öğrencileri mesleğe başlamadan önce belirli bir eğitim-öğretim sürecine yönlendirdiği için lisansüstü eğitim hedefinin kariyer planlama ile ilgili olduğunu söylemek olanaklıdır (Creed, Patton ve Prideaux, 2006; Toprak ve Erdoğan, 2013). Nitekim lisansüstü eğitime başlama kararları üzerinde etkili olan içsel etkenlerden (Ör. Yeni bilgi, deneyim ve ilişkiler isteği) biri de kariyer karar verme yetkinlik düzeyidir (Betz ve Hackett, 1986; Niles, Erford, Hunt ve Watts, 1997; Robbins, 1985). Bennett ve Turner'in (2012) "Lisansüstü Kariyer Deneyimi Anketi” adlı araştırmasının sonuçları, yetişkinlerin kariyer kararını etkileyen öğeleri tanımlamıştır. Anket sonuçları, istihdam olanaklarının iyileştirilmesi (\%59.5), finansal sermayeye erişim (\%35.5), kariyer yolunda ilerleme (\%58.7), kişisel ilgi (\%50.2), daha yüksek düzeyde yeterlik düzeyine ulaşma (\%37.7), kariyer değiştirmek (\%20.6), belirli bir meslek için gerekli olma koşulu (\%19.6) ve var olan iş veya mesleğin gereksinimleri (\%10) gibi öğelerin bireylerin kariyerlerine yatırım yapma kararında etkili olduğunu göstermiştir. Bu araştırmacılar, kariyer kararlarına etki eden etkenlerin bireylere özellikle lisansüstü eğitim seçiminin yapılabileceğine dayalı bir çerçeve sunduğu sonucuna varmıştır. Benzer şekilde Mellors-Bourne, Hooley ve Marriott'inin (2014) çalışmasında, kariyer karar verme yetkinliğinin bireyleri lisansüstü çalışmalara yönlendirmede açık bir rol oynadığ1 görülmüştür.

Alanyazında var olan diğer araştırmalar ise üniversite öğrencilerinin mezuniyetten sonra yüksek lisans programına katılmayı kariyer kararlarını kesinleştirme ve profesyonel yaşama adım atma isteğinden dolayı tercih ettiklerini ve bu süreci kariyer gelişiminde önemli bir aşama olarak gördüklerini göstermiştir (Akoğlan-Kozak ve Dalkıranoğlu, 2013; Lopatto, 2004; Pires, 2009; Tonbul, 2017).

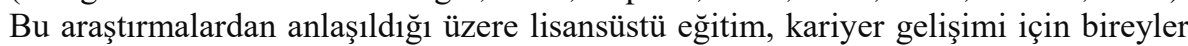
tarafından başvurulan anlamlı bir yoldur (Ertem, Engin, Demir ve Gökalp, 2017; Wisker, 2007). Buna göre lisansüstü eğitim planlaması mezunlar arasında kariyer planlama ve kariyer gelişimi açısından geçerli ve değerli bir süreç olarak kavramsallaştırılabilir.

\section{Lisansüstü Ĕ̆itim Farkındalığı}

Öğrencilerin üniversitede öğrenim gördüğü yıllar, aslında onların mesleki ya da akademik kariyerleri ile ilgili farkındalık ve olası niyetlerini keşfetme sürecidir (Martens ve Felissa, 1998). Lisans öğrencilerinin kariyer firsatlarını benimseme ve bunlarla ilgilenme derecesi akademik başarısına, kariyer farkındalığına ve yaşam önceliklerine bağlı olarak zaman içerisinde değişebilir (Akoğlan-Kozak ve Dalkıranoğlu, 2013; O'Grady ve Cottle, 2015). Araştırmalar, lisans deneyimlerinin lisans sonrası kariyer beklentileri üzerinde olumlu bir etkisinin olduğunu göstermiştir (Allen ve Zepeda 2007; Bauer ve Bennett 2003; Hathaway, Nagda ve Gregerman, 2002). Başarılı lisans deneyimine sahip öğrencilerin mezuniyet sonrası lisansüstü deneyimleri de içeren bir kariyer planının olması daha olasıdır. Bu nedenle öğrencileri 
kariyer planlama konusunda lisansüstü eğitim almaya yönlendirmek, onların gelecekteki meslek yaşamları açısından son derece önemlidir (Watson ve Stead, 1997). Ancak bu süreçte üniversitelerce öğrencilere gereken bilgi ve farkındalık kazandırılmadığında, mezuniyet sonrası plansız olarak iş yaşamına geçiş yapmaları, öğrencilerin kariyer amaçlarına yönelme süreçlerinde kaynak ve zaman kaybına uğramalarına yol açabilmektedir (Leung, Hou, Gati ve Li, 2011). Özellikle açık bir hedefi olmayan lisans öğrencilerinin lisans sonrası kariyer planlama konusunda karar alırken güçlükler yaşaması ve eğitimlerini devam ettirme yönünde karar almaları bu durumun ciddiyetini ortaya koymaktadır (Lopatto, 2004; Sangganjanavanich ve Magnuson, 2011).

Mezuniyet sonrası istihdam olanakları, kariyer etkinlikleri ile bağlantılı kişisel arayışlar ve iş yaşamında verimli çalışma koşullarını sağlama düşüncesi, lisans öğrencilerinin lisansüstü eğitime ilişkin farkındalıklarını ve lisansüstü kariyer niyetlerini etkileyebilmektedir. Lisansüstü eğitimle ilgili farkındalık, lisansüstü eğitim olanaklarından ve programlardan haberdar olmayı, lisansüstü programlara giriş koşulları, mesleki uzmanlık veya kariyer gelişimi açısından lisansüstü eğitimin önemi, lisansüstü eğitimin harcamalarını, lisansüstü öğrenim süreci ile ilgili ayrıntıları bilmeyi içermektedir (Varhegyi, 2009). Lisansüstü eğitime ilişkin farkındalık, lisansüstü eğitim alma kararında önemli bir etkendir. Lisans eğitimi sonrası kariyer kararı veren öğrencilerin lisansüstü eğitime ilişkin bilgi ve farkındalık düzeylerini artırdığı varsayılır (Neumann, 2003).

Bilgi ve farkındalık düzeyindeki bu artış iki anlama gelebilir (Jepsen ve Varhegyi, 2011). Birincisi, öğrencilerin lise ve üniversite yıllarında elde ettikleri deneyimlerin kariyerlerini etkilemede önemli etkileri bulunmaktadır. Henüz lisans öğreniminin başında kendisini belirli bir kariyer yoluna yönlendiren öğrenci, mezuniyet sonrası kariyerini biçimlendirmek için daha fazla çaba göstermeye ve akademik başarı elde etmeye çalışabilir. Bu davranışın gerçekleşmesinde yetenek ve çaba inançları, yaşam öncelikleri ve kariyer özlemleri gibi bilişsel, psikolojik, sosyal veya ekonomik düzey gibi çeşitli etkenler etkili olabilmektedir (Jepsen ve Neumann, 2010; Kuzgun, 2004; Sikora ve Pokropek, 2011). İkincisi, mevcut lisans öğrencilerine odaklanan üniversiteler, lisansüstü kariyere yönlendirmek için lisansüstü programlar tasarlayarak öğrencileri ile akademik diyaloglar gerçekleştirerek onların lisans sonrası eğitim ve kariyer olanakları hakkında bilgi ve farkındalık düzeylerini artırma çabasındadırlar. Araştırmalar bu görüşü destekler nitelikte lisans öğrencilerinin lisansüstü programlara ilişkin farkındalık düzeylerinin lisans sonrası bir lisansüstü programına devam etme kararlarını olumlu yönde etkilediğini doğrulamıştır (Jepsen ve Varhegyi, 2011; Varhegyi ve Jepsen, 2009a). Dolayısıyla lisansüstü eğitime yönelik farkındalık, yetişkinlerin dikkatini lisans diplomasının ötesine geçen kariyer fırsatlarına ve farklı eğitim olanaklarına yönlendirebilmektedir. 


\section{Araștırmanın Amacı ve Önemi}

$\mathrm{Bu}$ araştırmada, henüz lisans programında öğrenim gören lisans öğrencilerinin akademik başarısı (yani lisans not ortalaması) ile lisans sonrası lisansüstü eğitime başlama konusundaki niyetleri arasındaki ilișkide lisansüstü eğitim ile ilgili farkındalıklarının aracılık rolü incelenmiştir. Ayrıca akademik başarı, lisansüstü eğitim niyeti ve lisansüstü eğitim farkındalığı değişkenleri arasındaki olası doğrudan ve dolaylı ilişkiler sınanmıştır. Araştırmada alanyazındaki kuramsal açıklamalar ve önceki araştırma sonuçlarından hareketle akademik başarı ile lisansüstü eğitim niyeti arasındaki ilişside lisansüstü eğitim farkındalığının aracı rolünü açıklamaya dayalı bir model oluşturulmuş ve geliştirilen model üzerinde aracılık etkisi incelenmiştir. Lisans öğrencilerinin akademik başarı durumlarının lisansüstü eğitim ile ilgili farkındalık düzeyleri ile birlikte lisans sonrası lisansüstü eğitime devam etme konusundaki niyetlerini olumlu yönde yordayacağ 1 ileri sürülmektedir. Bu nedenle lisansüstü eğitim farkındalığının akademik başarı ve lisansüstü eğitim niyeti arasındaki ilişkiye aracılık edeceği düşünülmektedir.

Araştırmada akademik başarı değişkenine yer verilmesinin temel nedeni akademik başarının profesyonel başarı ve iş olanaklarının seçimi ile doğrudan ilişkili bir performans göstergesi olarak kabul edilmesi (Plant, Ericsson, Hill ve Asberg, 2005; Strenze, 2007) ve öğrenciler, üniversiteler hatta işverenler için anlamlı bir ölçüt olmasidır (Richardson, Abraham ve Bond, 2012). Nitekim bireyin kariyer kontrolü ve kariyer amaçlarının akademik başarısı tarafından yönlendirildiği varsayılır (Ayık, Özdemir ve Yavuz, 2007; Büyükgöze-Kavas, 2011; Gianakos, 1999; Niles ve diğ., 1997). Çünkü akademik başarının öğrencilerin yetişkinliğe geçerken izledikleri mesleki yol ve kariyer hedefleri üzerinde güçlü bir etkisi vardır (Poropat, 2009). Bandura'ya (1991) göre, akademik başarıya ilişkin algılanan öz-yetkinlik ve akademik benlik saygısı ne kadar yüksek olursa o kadar daha iddialı zorluklar izlenir ve daha büyük başarı hedefleri belirlenir. Bandura'nın Sosyal Bilişsel Kuramı doğrultusunda geliştirilen Sosyal Bilişsel Kariyer Kuramı'nda ise kariyer gelişimi sürecinde bilişsel durum olarak ele alınan yetkinlik beklentisinin önemine vurgu yapılmaktadır (Lent, Brown ve Hackett, 1994). Yetkinlik beklentisi, kişinin farklı performansları gerçekleştirebileceğine veya hedefleri başarabileceğine ilişkin özinançları tanımlamaktadır (Lent, 2005).

Sosyal Bilişsel Kariyer Kuramı'nda, güçlü akademik yetkinlik beklentilerine sahip bireylerin kariyer seçeneklerinin daha fazla olduğu, bu seçeneklerin ilgi ve yetenekleriyle doğrudan bir ilişkisinin bulunduğu; kendilerini daha farklı kariyer seçenekleri için hazırlayabildikleri ve seçtikleri alanda uzmanlaşma isteğinde oldukları belirtilmektedir (Lent, Brown ve Hackett, 2002). Sonuç olarak akademik başarı, kariyer karar verme yetkinlik düzeyini artırmaktadır (Bandura, 1977, 1997) böylece kariyer ile ilgili kararlar almada bireyin daha yetkin olmasını sağlayarak kariyer yollarını çizmesine yardımcı olmaktadır. Araştırmalar, akademik not ortalamasının lisansüstü eğitime katılımda etkili ve güvenilir bir performans 
göstergesi olduğunu doğrulamıştır (Corominas, Saurina ve Villar 2010; Karakul ve Karakütük, 2014; Kim ve diğ., 2016; Scarbecz ve Ross, 2007).

Alanyazın incelemeleri sonucunda Türkiye'de lisans öğrencilerinin lisansüstü eğitim alma kararlarını etkileyen etkenler konusundaki araştırmalar sınırlı düzeydedir (Alabaş, Kamer ve Polat, 2012; Aydemir ve Çam, 2015; Çoruk, Çağatay ve Öztürk, 2016; Erkılıç, 2007; Karadaş, Duran ve Kaynak, 2017; Özlem, Hazar, Kılıç ve Korkmaz, 2015; Ünal ve İlter, 2010). Bununla birlikte üniversite öğrencilerinin akademik başarısı, lisansüstü eğitime ilişkin farkındalığı ve lisansüstü kariyer niyetleri arasındaki ilişkileri inceleyen herhangi bir çalışmanın olmadığı belirlenmiştir. $\mathrm{Bu}$ durumun lisans öğrencilerinin lisansüstü eğitim konusunda farkındalık düzeylerini ve bu eğitime devam etme niyetlerini ölçen özel bir psikometrik aracın bulunmamasından kaynaklandığı düşünülmektedir. Bu gereklilikler çerçevesinde bu araştırmada öncelikle henüz lisans öğrenimi aşamasında olan öğrencilerin lisansüstü eğitime devam etme niyetlerini ve lisansüstü eğitime yönelik farkındalık düzeylerini belirlemeye dayalı ölçme araçları geliştirilmiştir. Bu adımdan sonra, araştırmada lisans düzeyinde öğrenim gören öğrencilerin akademik başarı ortalamaları ve lisansüstü eğitime ilişkin farkındalık düzeylerinin mezuniyet sonrası lisansüstü eğitime devam etme niyetleri üzerindeki etkisi yapısal eşitlik modellemesi aracılığıyla incelenmiş ve bu sayede alanyazındaki boşluğun doldurulması hedeflenmiştir.

Henüz lisans öğrenimi aşamasında olan öğrencilerin gelecekte bir lisansüstü programa devam etme niyetlerini etkileyen olası değişkenlerin incelenmesi önemli olabilir, çünkü bu değişkenlerin anlaşılması, öğrencilerin geleceğine ilişkin bilinçli eğitimsel ve mesleki seçimler yapmaları için kişisel yetkinlikleri hakkında yeterli bir farkındalığa sahip olmalarını sağlamaya yardımcı olabilir. Ayrıca akademik başarı, kariyer farkındalığı ve kariyer kararı gibi bilişsel etkenlerin lisansüstü kariyeri kavramsallaştırmada önemli olacağı düşünülmektedir. Akademik başarı, lisansüstü eğitim farkındalığı ve lisansüstü eğitim niyeti değişkenlerinin bir çalışmada birlikte ele alınarak açıklayıcı ve yordayıcı ilişkilerinin ortaya çıkarılması üniversite öğrencilerinin lisans sonrası eğitim hedeflerine ve bu hedeflerin biçimlendirilmesine dahil olan sürecin daha iyi anlaşılmasına yardımcı olabilir. Bu bakımdan lisansüstü eğitim kararını etkileyen ilgili değişkenlerin incelenmesine dayalı bir araştırmanın yürütülmesi yerinde olacaktır.

\section{Araştırmanın Hipotezleri}

Henüz lisans öğrenimi aşamasında olan öğrencilerin akademik başarısı, lisansüstü eğitim ile ilgili farkındalık düzeyleri ve lisansüstü eğitim niyetleri arasındaki ilişkileri incelemek amacıyla yapılan bu araştırmada oluşturulan modelin hipotezleri şu şekildedir.

Hipotez 1. Akademik başarı, lisansüstü eğitim farkındalığının anlamlı bir yordayıcisidir. 
Hipotez 2. Lisansüstü eğitim farkındalığı, lisansüstü eğitime başlama ile ilgili niyetin anlamlı bir yordayıcısıdır.

Hipotez 3. Akademik başarı, lisansüstü eğitime başlama ile ilgili niyetin anlamlı bir yordayıcısıdır.

Hipotez 4. Akademik başarı ile lisansüstü eğitim niyeti arasındaki ilişkide lisansüstü eğitim farkındalığının aracılık rolü bulunmaktadır.

\section{Yöntem}

Araştırmanın bu bölümünde çalışmanın modeline, örneklemine, veri toplama araçlarına ve verilerin çözümlenmesine ilişkin bilgilere yer verilmektedir.

\section{Araştırma Modeli}

$\mathrm{Bu}$ araştırmada, akademik başarı ile lisansüstü eğitim niyeti değişkenleri arasındaki ilişkide lisansüstü eğitime ilişkin farkındalığın aracılık rolü incelenmiştir. $\mathrm{Bu}$ doğrultuda değişkenler arasındaki ilişkileri incelemek için yapısal eşitlik modellemesi (YEM) kullanılmıştır. YEM'in kullanılmasındaki amaç, oluşturulan hipotetik modelin çalışma sonucunda ulaşılan verilerle ne derece desteklendiğini anlamaktır (Schumacker ve Lomax, 2010). Araştırmanın hipotezlerinden yola çıkarak değişkenler arasındaki ilişkileri ve bu ilişkilerin yönünü gösteren hipotetik model Şekil 1'de verilmiştir.

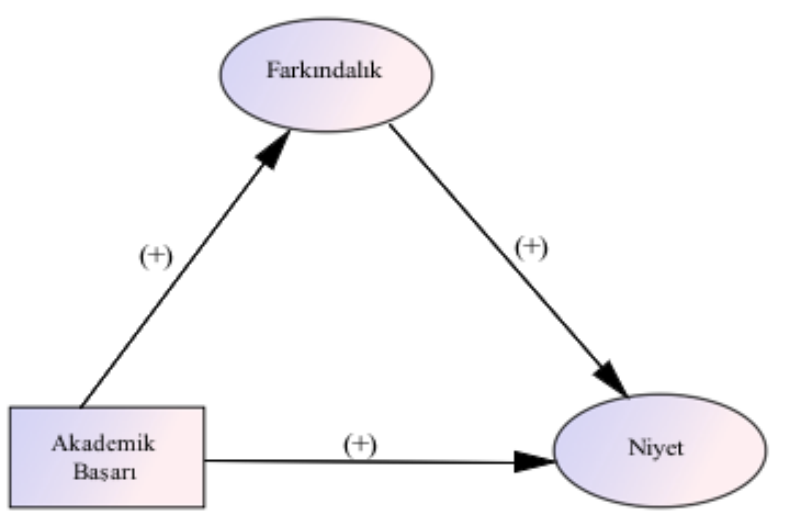

Şekil 1. Değişkenler arasındaki ilişkileri gösteren hipotetik model

\section{Evren-Örneklem}

Araştırmanın evrenini 2018-2019 öğretim yılında Kahramanmaraş Sütçü İmam Üniversitesinin Eğitim Fakültesinin çeşitli bölümlerinde (Sosyal Bilgiler Eğitimi, Türkçe Eğitimi, Matematik Eğitimi, Sınıf Eğitimi, Fen Bilgisi Eğitimi ile Rehberlik ve Psikolojik Danışmanlık) tüm sınıf (1, 2, 3 ve 4. Sınıf) düzeylerinde öğrenim gören 
öğrenciler oluşturmaktadır. Bu doğrultuda araştırmanın örneklemini 255’i (\%61.44) kadın ve 160’1 (\%38.56) erkek olmak üzere toplam 415 öğrenci oluşturmaktadır. Katılımcılara ilişkin bilgiler incelendiğinde, öğrencilerin 96'sı (\%23.13) birinci sınıf, 94 'ü (\%22.65) ikinci sınıf, 108'i (\%26.02) üçüncü sınıf ve 109’u (\%26.26) dördüncü sınıfta öğrenim görmektedir. Yaşları 18 ile 35 arasında değişmekte olan öğrencilerin yaş ortalaması 21.19 (ss= 4.38) olarak bulunmuştur. Tüm sınıf düzeylerinde öğrencilerin katılımına yer verilmesinin nedeni ise yükseköğretim sürecinin öğrencilerin gelecekteki kariyerleri ile ilgili kararlar aldıkları ve planlama yaptıkları önemli bir dönem olmasıdır (Harackiewicz, Barron, Tauer ve Elliot, 2002). Martens ve Felissa'a (1998) göre, üniversite öğrencilerinin birinci ve ikinci yılları kariyerleri ile ilgili bir keşif aşaması olup, kariyer seçimi ve kariyer araştırması bu dönemde değerlendirilebilir. Örneğin ikinci sınıf öğrencileri, lisans derecelerinin sona ermesini bekleyebilir ve öğrencilerin lisans derecesinin ardından bir yüksek lisans programına katılarak akademik bir çalışma yapmayı düşünmeleri de olasıdır. Üçüncü sınıf öğrencilerinin ise istihdam seçenekleri hakkında düşünmekle ve hazırlık yapmakla ayrıca etkin olarak lisans sonrası kariyer firsatları ve istihdam bilgileri aramakla ilgilenmeleri olasıdır (Jepsen ve Varhegyi, 2011). Araştırmada, öğrencilerin öğrenim gördükleri yıllardaki genel not ortalaması akademik başarı değişkeni olarak alınmıştır. Buna göre araştırmaya katılan öğrencilerin bildirdiği lisans not ortalaması 1.85 ile 3.88 arasında değişmektedir $(\overline{\mathrm{x}}=2.85, \mathrm{ss}=12.98)$.

Çalışma Grubu 1. 68'i erkek (\%45.33) ve 82'si kadın (\%54.67) olmak üzere toplam 150 öğrenciden oluşmaktadır. Öğrencilerin 40’1 (\%26.67) birinci sınıfta, 35’i (\%23.33) ikinci sınıfta, 38'i (\%25.33) üçüncü sınıfta ve 44'ü (\%24.67) ise dördüncü sınıfta öğrenim görmektedir. Bu örneklemden toplanan verilerle veri toplama araçlarının geliştirilmesi amacıyla açımlayıcı faktör analizi yapılmıştır.

Çalışma Grubu 2. 173’ü kadın (\%65.28) ve 92'si (\%34.72) erkek olmak üzere toplam 265 öğrenciden oluşturmaktadır. Sınıflara göre dağılımlar incelendiğinde, öğrencilerin 56's1 (\%21.13) birinci sınıfta, 59'u (\%22.26) ikinci sınıfta, 70’i (\%26.41) üçüncü sınıfta ve 75'i (\%30.2) dördüncü sınıfta öğrenim görmektedir. Bu örneklemden toplanan verilerle doğrulayıcı faktör analizi ve YEM analizi yapılmıștır.

\section{Veri Toplama Araçları}

Araştırmada kullanılan kişisel bilgi formu, Lisansüstü Eğitim Niyeti Ölçeği ve Lisansüstü Eğitim Farkındalığı Ölçeği araştırmacı tarafından bu araştırmanın amacı ve hipotezleri doğrultusunda geliştirilmiştir. Ölçme araçları yoluyla elde edilen verilerin parametrik testlere uygun olup olmadığını belirlemek amacıyla araştırmada öncelikle elde edilen verilerin normallik varsayımını karşılayıp karşılamadığı incelenmiştir. Normallik varsayımının karşılanıp karşılanmadığını incelemek için QQ grafiği, basıklık ve çarpıklık değerleri incelenmiş ve Kolmogorov-Smirnov testi yapılmıştır (Tabachnick ve Fidell, 2007). Verilerin analizinde SPSS 22.0 veri analizi programı kullanılmıştır. Bu kapsamda verilerin normal dağılım gösterip göstermediğini belirlemek amacıyla öncelikle Q-Q olasılık grafiği incelenmiştir. Q-Q grafiğine göre elde edilen veriler, beklenen normallik doğrusuna yakındır. Verilerin 
basıklık ve çarpıklık değerleri incelendiğinde ise verilerin basıklık ve çarpıklık katsayılarının -.38 ile .22 arasında değiştiği görülmüştür. Bu değerler -1.96 ile +1.96 arasında yer aldığından araştırmada elde edilen verilerin normal dağılıma sahip oldukları söylenebilir. Bununla birlikte Kolmogorov-Smirnov $(p=.18)$ testinin $p$ değerinin .05'ten büyük olması ise yine verilerin normalliğin sağlandığını kanitlamaktadir (Can, 2014).

Kişisel Bilgi Formu: Öğrencilerin cinsiyet, akademik başarı ve sınıf düzeyi ile ilgili veriler araştırmacı (yazar) tarafından hazırlanan kişisel bilgi formuyla elde edilmiştir. Akademik başarı öğrencilerin 2018-2019 öğretim yılındaki lisans not ortalamasını (4'lük not sistemi üzerinden) göstermektedir.

Lisansüstü Eğitim Farkındalığı Ölçeği: Bu araştırmada, henüz lisans öğrenimi aşamasında olan öğrencilerin lisansüstü programlar ve derecelerden ne ölçüde haberdar olduklarını, lisansüstü eğitimin kariyer gelişimi açısından önemi ve lisansüstü eğitimin katkıları konusundaki farkındalık düzeylerini ölçmek için "Lisansüstü Eğitim Farkındalığı Ölçeği”" geliştirilmiştir. Ölçeğin geliştirilme sürecinde lisansüstü eğitim ile ilgili önceki araştırmalar ve alanyazındaki kuramsal açıklamalar incelenmiştir (Artess ve Hooley, 2017; Karakütük, 2002; Lent ve diğ., 1994; YÖK, 2016; Wisker, 2007). Bu amaçla araştırmacı tarafından henüz lisans öğrenimi aşamasında olan öğrencilerin lisansüstü eğitime ilişkin farkındalık düzeylerini belirlemeye dayalı 10 madde hazırlanmıştır. Denemelik ölçek 5'li Likert tipinde ölçek olarak düzenlenmiştir ( $1=$ Hiç katılmıyorum, $2=$ Katılmıyorum, $3=$ Klsmen katılyyorum, 4= Katılıyorum ve 5= Tamamen katılıyorum). Hazırlanan maddeler kapsam ve görünüş geçerliği için ölçme-değerlendirme alanında doktora derecesine sahip olan iki uzmanın görüşüne sunulmuştur. Uzmanlardan gelen yorumlar daha açık ve sade bir anlatım için ölçeğin deneme formundaki dört maddenin benzer ifadelerinden dolayı ölçek kapsamından çıkarılması gerektiği yönünde olmuştur. Toplamda altı maddeden oluşan nihai ölçek araştırmanın ilk örneklemine uygulanmıştır.

\section{Ölçeğin Yapı Geçerliği}

Açımlayıcı Faktör Analizi. Araştırmada hazırlanan ölçeğin yapı geçerliğini incelemek için açımlayıcı faktör analizi (AFA) yapılmıştır. Ölçeğin yap1 geçerliğini belirlemeden önce örneklem büyüklüğünün faktör analizine uygun olup olmadığını belirlemek için ise Kaiser Meyer-Olkin (KMO) ve Bartlett Küresellik testleri yapılmıştır. Elde edilen sonuçlara göre ölçeğin KMO değeri .83 olarak bulunmuştur. Faktör analizinde KMO değerinin .60'dan yüksek olması önerilmektedir (Pallant, 2001; Tabachnick ve Fidell, 2007). Bartlett küresellik testi sonucu ise anlamlı $\left[\chi^{2}=\right.$ 2674.01; $<<.000$ ] bulunmuştur (Thompson, 2004). KMO ve Barlett testlerinden elde edilen sonuçlar verilerin faktör analizine uygun olduğunu göstermektedir. Bu adımdan sonra ölçeğin yapı geçerliğini belirlemek için AFA yapılmıştır. Faktör analizinde öz-değeri 1'in üstünde olan faktörler temel alınmıştır (Büyüköztürk, 2014). AFA sonuçları ölçeğin öz-değeri 1'den büyük ve toplam varyansın \%51.12'sini açıklayan tek faktörden oluştuğunu ortaya koymuştur. Kline (2015) ölçek geliştirme 
çalışmalarında açıklanan varyans oranının en az \%40 olması gerektiğini belirtmiştir. Buna göre AFA sonucunda hesaplanan varyans değerinin ölçeğin faktör yapısına karar vermekte yeterli olduğu söylenebilir. Öte yandan ölçeğin maddelerinin faktör yük değerlerinin .42 ile .78 arasında değiştiği bulunmuştur. Araştırmacılar madde faktör yük değerlerinin en az .40 olması gerektiğini önermiştir (DeVellis, 2003; Field, 2009; Kline, 2015). Bu çerçevede ölçeğin tek boyutlu yapısında bulunan tüm maddelerin madde faktör yük değerlerinin yeterli olduğu söylenebilir. Lisansüstü Eğitim Farkındalığı Ölçeği’ndeki tüm maddeler olumlu ifadelerden oluşmaktadır (Örnek madde: "Lisansüstü eğitimi, kariyer seçimi ve kariyer planlama ile ilgili kararlarda önemli bir yardım alma yolu olarak görüyorum”). Ölçekten elde edilebilecek olası puanlar altı ile otuz arasında değişmekte ve yüksek puanlar öğrencilerin yüksek veya doktora gibi lisansüstü eğitim programları ve bu eğitimin olanakları ile ilgili farkındalık düzeylerinin yüksekliğine işaret etmektedir. Tablo 1' de Lisansüstü Eğitim Farkındalığı Ölçeği'nin faktör analizi sonuçlarına yer verilmiştir.

Tablo 1

Lisansüstü Eğitim Farkındalı̆̆ Ölçeği Faktör Yükleri

\begin{tabular}{lc}
\hline Lisansüstü Eğitim Farkındalığı Ölçeği & Faktör Yükleri \\
\hline $\begin{array}{l}\text { Alanımda kariyer planlama ve/veya istihdam seçenekleri için } \\
\text { lisansüstü programların ve seçeneklerin farkındayım. }\end{array}$ & .78 \\
\hline $\begin{array}{l}\text { Lisansüstü eğitimi, kariyer seçimi ve kariyer planlama ile ilgili } \\
\text { kararlarda önemli bir yardım alma yolu olarak görüyorum. }\end{array}$ & .73 \\
\hline $\begin{array}{l}\text { Lisansüstü eğitimin bir alanda uzmanlaşmanın önemli bir gereği } \\
\text { olduğunu düşünüyorum. }\end{array}$ & .69 \\
\hline $\begin{array}{l}\text { Lisans öğrenimi sürdürülürken ileride lisansüstü düzeyde eğitime } \\
\text { devam etme düşüncesinin yaygınlaştığını düşünorum. }\end{array}$ & .62 \\
\hline $\begin{array}{l}\text { Lisansüstü programlar ve verilen dereceler hakkında nereden, kimden } \\
\text { veya nasıl bilgi alınacağını biliyorum. }\end{array}$ & .61 \\
\hline $\begin{array}{l}\text { Lisansüstü programlara giriş için gerekli başvuru koşullarının } \\
\text { farkındayım. }\end{array}$ & .42 \\
\hline $\begin{array}{l}\text { Açıkladığı Toplam Varyans } \\
\text { Kaiser-Meyer-Olkin (KMO) }\end{array}$ & $\% 51.12$ \\
\begin{tabular}{l} 
Bartlett Küresellik Testi \\
\hline
\end{tabular} & .83 \\
\hline
\end{tabular}

Ölçeğin Doğrulayıcı Faktör Analizi Sonuçları. Lisansüstü Eğitim Farkındalığı Ölçeği'nin AFA ile belirlenen tek boyutlu yapısının geçerliğine ilişkin kanıt elde etmek için (DeVellis, 2003) doğrulayıcı faktör analizi (DFA) yapılmıştır. Doğrulayıcı faktör analizi, değişkenler arasındaki ilişkiye yönelik önceden saptanan bir modelin ya da hipotezin test edilmesi işlemidir (Büyüköztürk, 2014). Doğrulayıcı faktör analizi AMOS 22.0 veri analizi programı kullanılarak yapılmıştır. DFA için çoklu uyum indeksleri kullanılmıştır. Model uyum indeksleri, test edilen modelin kabul 
edilip edilmeyeceğini değerlendirmek için kullanılan ölçütler olarak tanımlanır (Kline, 2015). Bu araştırmada Ki-kare uyum testi, RMSEA (Root Mean Square Error of Approximation), NFI (Normed Fit Index), Standardized RMR, GFI (Goodness of Fit Index), TLI (Tucker-Lewis coefficient Index), CFI (Comparative Fit Index) ve IFI (Incremental Fit Index) uyum indeksleri kullanılmıştır. GFI, CFI, NFI ve IFI indeksleri için kabul edilebilir uyum değeri için alt sınır .90 ve mükemmel uyum değeri için ise 95 olarak kabul edilmektedir (Bayram, 2010; Hu ve Bentler, 1999; Meydan ve Şeşen, 2015; Şimşek, 2007). RMSEA için ise .08 ve altı kabul edilebilir uyum ve .05 ve altı ise mükemmel uyum değeri olarak kabul edilir (Browne ve Cudeck, 1993; Byrne ve Campbell, 1999; Cole, 1987). Yapılan DFA sonuçlarına göre oluşturulan altı maddelik ölçme aracının tek faktörlü yapısının iyi bir uyum gösterdiği bulunmuştur. Uyum indeksleri incelendiğinde bütün uyum indeksleri bir arada değerlendirildiğinde kurgulanan modelin doğrulandiğ ${ }_{1}$ söylenebilir $\left(\chi^{2} / \mathrm{sd}=2.11\right.$, RMSEA $=.06, \mathrm{GFI}=.93, \mathrm{CFI}=.95, \mathrm{SRMR}=.06, \mathrm{NFI}=.90, \mathrm{IFI}=.95, \mathrm{TLI}=.90)$. Ölçeğin DFA regresyon katsayıları .58 ile .82 arasında değişmekte olup tüm maddelerin faktör yükleri anlamlı bulunmuştur $(\mathrm{p}<.05)$. Şekil 2'de Lisansüstü Eğitim Farkındalığı Ölçeği’ne ilişkin doğrulayıcı faktör analizi sonuçları verilmiştir.

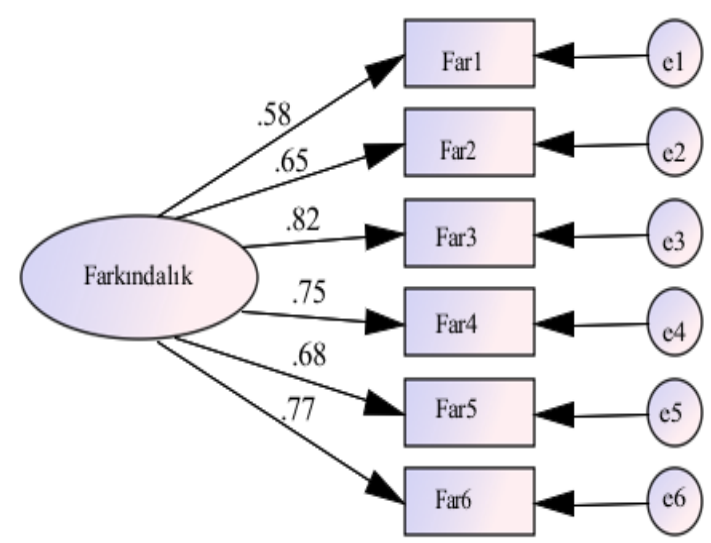

Şekil 2. Lisansüstü Eğitim Farkındalığı Ölçeği doğrulayıcı faktör analizi sonuçları

\section{Ölçeğin Güvenirlik Çalışmaları}

Bu araştırmada, Lisansüstü Eğitim Farkındalığı Ölçeği’nin DFA sonucunda elde edilen tek faktörlü yapısına yönelik iç tutarlık katsayısı, bileşik (yapı) güvenirliği (Composite Reliability-CR) ve ortalama açıklanan varyans değerleri (Average Variance Extracted-AVE) hesaplanmıştır. Bileşik güvenirlik, iç tutarlığa bağlı bir güvenirlik katsayısı olup DFA sonucunda elde edilen faktör yükleri ve hata varyanslarına dayalı olarak hesaplanmaktadır (Yang ve Green, 2011). Yakınsak geçerliğin sağlanması için CR değerinin .70'den AVE değerinin ise .50'den yüksek olmas1 gerekmektedir (Byrne 2010; Fornell ve Larcker, 1981). Fornell ve Larcker 
(1981) bir ölçme aracının yapı geçerliğini belirlemek için her bir faktörden elde edilen AVE değerine göre yakınsak geçerliğinin ortaya konması gerektiğini önermiştir. Ölçümlere ilişkin hesaplanan bileşik güvenirlik değerinin .86 olduğu görülmüştür. AVE değeri ise .51 olarak hesaplanmıştır. Hair, Black, Babin, Anderson ve Tatham (2006) yakınsak geçerliği için, AVE değerinin .5'ten yüksek olmasını ve CR değerinin ise AVE değerinden yüksek olması gerektiğini belirtmiştir (CR>AVE; AVE> .5) Elde edilen değerler incelendiğinde, ölçeğin tek faktörlü yapısına ilişkin CR değerinin AVE değerinden büyük olduğu ve AVE değerinin ise .50'den büyük olduğu görülmüştür. Bu değerlere göre ölçeğin yakınsak geçerliğinin sağlandığı söylenebilir. Ölçeğin iç tutarlık güvenirliğinin belirlenmesinde Cronbach Alfa katsayısı $(\alpha)$ hesaplanmıştır. Ölçeğin tamamı için elde edilen Cronbach alfa katsayısı .88 olarak hesaplanmıştır. Cronbach Alfa katsayılarının değerlendirilmesinde, Alfa katsayısı .40 'ın altında olması durumunda ölçeğin güvenilir olmadığı, .40 ile .60 arasında olması durumunda ölçeğin düşük güvenirlikte olduğu, .60 ile .80 arasında olması durumunda ölçeğin yüksek derecede güvenilir olduğu, .80 ile 1 arasında olması durumunda ise ölçeğin yüksek derecede güvenilir olduğu kabul edilmektedir (Özdamar, 1999). Yapılan geçerlik ve güvenirlik çalışmalarından sonra Lisansüstü Eğitim Farkındalığı Ölçeği’nin henüz lisans programında öğrenim gören öğrencilerin lisansüstü eğitime ilişkin farkındalık düzeylerini değerlendirebilecek özellikte olduğu söylenebilir.

Lisansüstü Eğitim Niyeti Ölçeği: Araştırmada henüz lisans programına devam eden öğrencilerin lisansüstü eğitime ne ölçüde devam etmeyi düşündüklerini değerlendirmek amacıyla Lisansüstü Eğitim Niyeti Ölçeği geliştirilmiştir. Ölçeğin geliştirilme sürecinin ilk aşamasında üniversite öğrencilerinin lisansüstü eğitime başlamayla ilgili isteklerine, lisansüstü eğitim alma isteklerinin gerekçelerine (Ör. Kariyer olarak akademisyenlik) ve lisansüstü programlara giriş için koşulları sağlayıp sağlamama hazırlığına yönelik öğrenci görüşleri alınmıştır. Bu amaçla denemelik madde yazımı için bu araştırma kapsamında olmayan 20 lisans öğrencisine lisansüstü eğitim niyetlerine/hedeflerine dayalı hazırlanan açık-uçlu sorular sorulmuş ve görüşler alınmıştır. Görüşme soruların hazırlanmasında lisansüstü eğitimle ilgili araştırma bulgularından yararlanılmıştır (Jepsen ve Neumann, 2010; Neumann, 2003; Ling-Yi, 2006; Ünal ve İlter, 2010). Görüşme sorularına birkaç örnek "Lisansüstü eğitim almayı planlıyor musunuz? Yanıtınız "Hayır." ise bunun için iki neden belirtebilir misiniz? Eğer cevabınız "Evet." ise (a) "Ne zaman planliyorsunuz?", (b) "Neden planlıyorsunuz? c) "Hangi lisansüstü eğitim derecesini almayı planlıyorsunuz?" (Yüksek lisans mı doktora mı?); (d) "Eğer bir lisansüstü programa kabul edilirseniz lisansüstü eğitimden beklentileriniz nelerdir? e) Lisansüstü eğitiminizi tamamlamanızın size neler katacağını düşünüyorsunuz? Öğrencilerin açık-uçlu sorulara verdiği yanıtlardan hareketle lisansüstü eğitime devam etme niyetlerini değerlendiren 10 maddelik 5'li Likert tipinde ( $1=$ Hiç katılmıyorum, $2=$ Katılmıyorum, $3=$ Kısmen katıllyorum, 4=Katılıyorum ve 5= Tamamen katıllyorum) taslak bir ölçek geliştirilmiştir. Bu adımdan sonra, ölçeğin kapsam geçerliği için uzman görüşlerine başvurulmuştur. Uzmanlardan gelen geribildirimler dikkate 
alınarak ilgili maddelerde düzenlemelere gidilmiştir. Ölçekte gerekli düzeltmeler yapıldıktan sonra altı maddeden oluşan taslak bir ölçek formu oluşturulmuştur.

Hazırlanan ölçeğin yapı geçerliğini incelemek için araştırmada ilk örneklemden elde edilen veriler üzerinde AFA yapılmıştır. Öncelikle ölçeğin KMO ve Bartlett Küresellik testleri yapılmıştır (Büyüköztürk, 2014). KMO değeri .71 Bartlett testi ise $2953.28(\mathrm{p}<.000)$ olarak belirlenmiştir. KMO'nun .60'dan yüksek ve Barlett testinin de anlamlı çıkması veri seti üzerinde faktör analizinin yapılabileceğini göstermektedir (Çokluk, Şekercioğlu ve Büyüköztürk, 2016). Faktör analizi sonucunda altı maddenin öz-değeri 1'den yüksek olan ve toplam varyansın \%55.56'sını açıklayan tek faktör altında toplandığ 1 bulunmuştur. Ölçeğin maddelerinin faktör yükleri .47 ve .75 arasında değişmektedir. Ölçekteki toplam puanların artması, mezuniyet sonrası bir lisansüstü programa başlama ile ilgili niyetin yüksekliğini göstermektedir. Faktör analizi sonucunda ölçeğin madde faktör yük değerleri Tablo 2'de sunulmuştur.

Tablo 2

Lisansüstü Eğitim Niyeti Ölçeği Faktör Yükleri

\begin{tabular}{|c|c|}
\hline Lisansüstü Eğitim Farkındalığı Ölçeği İfadeleri & Faktör Yükleri \\
\hline $\begin{array}{l}\text { Lisansüstü eğitim, akademik odaklı kişisel yeteneklerimi ve } \\
\text { performansımı geliştirme firsatıdır. }\end{array}$ & .70 \\
\hline $\begin{array}{l}\text { Bir alanda lisans eğitiminin tamamlanmasının ardından lisansüstü } \\
\text { yeterliklerinin de elde edilmesi gerektiği düşüncesindeyim. }\end{array}$ & .75 \\
\hline $\begin{array}{l}\text { Sürdürmekte olduğum lisans programını tamamladıktan sonra } \\
\text { lisansüstü eğitime başlamak istiyorum. }\end{array}$ & 63 \\
\hline $\begin{array}{l}\text { Lisans eğitimini tamamladıktan sonra, lisansüstü düzeyde öğrenim } \\
\text { görmek için gerekli koşulları sağlamaya çalışıyorum. }\end{array}$ & .55 \\
\hline $\begin{array}{l}\text { Lisansüstü eğitimi, mesleki alanda uzmanlaşma ve yükselme } \\
\text { amaciyla düşünüyorum. }\end{array}$ & .58 \\
\hline $\begin{array}{l}\text { Lisansüstü eğitimi, akademik kariyer yapma isteğimden dolay1 } \\
\text { düşünüyorum. }\end{array}$ & .47 \\
\hline $\begin{array}{l}\text { Açıkladığı Toplam Varyans } \\
\text { KMO }\end{array}$ & $\begin{array}{c}\% 55.56 \\
.71\end{array}$ \\
\hline Bartlett' Küresellik Testi & $\begin{aligned} \chi^{2} & =2953.28 \\
p & <.001\end{aligned}$ \\
\hline
\end{tabular}

Ölçeğin Doğrulayıcı Faktör Analizi. Lisansüstü Eğitim Niyeti Ölçeği’nin AFA sonucunda elde edilen tek faktörlü yapısının uygunluğu AMOS 22.0 veri analizi programı kullanılarak DFA ile incelenmiştir. DFA araştırmanın ikinci çalışma grubundan toplanan verilerle yapılmıștır. Modelin uyum indekslerinin değerlendirilmesinde $\chi^{2}, \chi^{2} / \mathrm{sd}$, GFI, CFI, IFI, RMSEA ve SRMR değerleri kullanılmıştır. DFA sonuçlarına göre, ölçeğin altı maddelik tek faktörlü yapısının bir model olarak doğrulandığı ve modele ait uyum indekslerinin yeterli olduğu bulunmuştur $\left(\chi^{2} / \mathrm{sd}=2.24 ; \mathrm{RMSEA}=.061 ; \mathrm{GFI}=.92 ; \mathrm{CFI}=.95 ; \mathrm{NFI}=.92, \mathrm{TLI}=\right.$ 
92, IFI $=.95)$. Ölçeğin tek faktörlü modeli için standardize edilmiş regresyon katsayıları .54 ile .78 değerleri arasında değişmekte olup istatistiksel olarak anlamlı bulunmuştur $(\mathrm{p}<.05)$. Doğrulayıcı faktör analizi bulguları Şekil 3 'te verilmiştir.

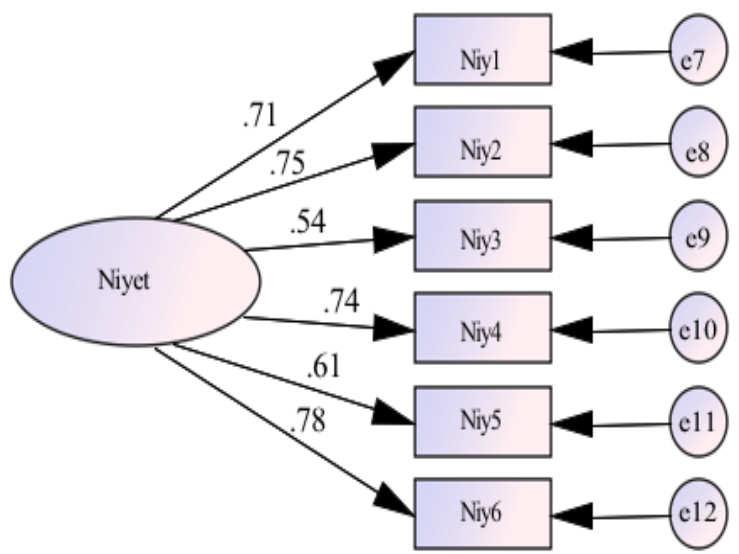

Şekil 3. Lisansüstü Eğitim Niyeti Ölçeği doğrulayıcı faktör analizi sonuçları

Lisansüstü Eğitim Farkındalığı Ölçeği’nde olduğu gibi Lisansüstü Eğitim Niyeti Ölçeği'nin de bileşik güvenirlik ve ortalama açıklanan varyans değerleri hesaplanmıştır. Ölçeğin tek boyutu için elde edilen bileşik güvenirlik katsayısı .84 olarak belirlenmiştir. Bununla beraber AVE değeri .48 olarak hesaplanmıştır. Araştırmada daha önceden de söz edildiği gibi, yakınsak geçerlik için AVE değerlerinin .50'den, CR değerlerinin ise .70'den yüksek olması önerilmektedir. Ölçeğin CR değerinin .70'in üzerinde olduğu ve AVE değerinin .50'in altında olduğu görülmüştür. Ancak bu değer kabul edilebilir düzeydedir. Çünkü Hair ve diğerleri (2006) tarafindan CR değerleri .60'dan yüksek olduğu durumda, AVE'nin .50'den düşük olmasının kabul edilebilir olduğu ve yakınsak geçerlik için yeterli olduğu belirtilmektedir. Ölçeğin Cronbach Alfa iç tutarlık katsayısı ise .81 olarak hesaplanmıştır. Sonuç olarak Lisansüstü Eğitim Niyeti Ölçeği'nin güvenirliğini belirlemeye yönelik olarak elde edilen tüm sonuçlar, bu ölçeğin geçerli ve güvenilir bir araç olduğunu ortaya koymaktadır.

\section{İşlem}

Akademik başarı, lisansüstü eğitim farkındalığı ve lisansüstü eğitim niyeti arasındaki ilişkiler ağını belirlemeyi amaçlayan bu araştırmada öncelikle değişkenlere yönelik betimsel istatistikler ve değişkenler arası ilişkiler ortaya konulmuştur. Değişkenler arası ilişkiler Pearson momentler çarpımı korelasyon katsayısı ile hesaplanmıştır. Korelasyon analizinin yorumlanmasında .00-.29 aralığı düşük, .30-.69 aralığı orta ve .70-1.00 aralığı da yüksek düzeyde ilişki olarak kabul edilmiştir (Büyüköztürk, 2014). Araştırmada, lisansüstü eğitim farkındalığının ve akademik 
başarının lisansüstü eğitim niyeti üzerindeki yordayıcı etkisi yapısal eşitlik modellemesi (YEM) ile incelenmiştir. Modelde akademik başarı değişkeni yordayıcı örtük değişken olarak yer alırken, lisansüstü eğitim farkındalığı yordayıcı gözlenen değişken olarak yer almıştır. Yordanan değişken olan lisansüstü eğitim niyeti ise örtük (gizil) değişken olarak modelde yer almıştır. Model uyumunun değerlendirilmesinde $\chi^{2}$, sd, $\chi^{2} / \mathrm{sd}$, GFI, CFI, IFI, TLI, SRMR ve RMSEA uyum indeksleri kullanılmıştır. Modelin değerlendirilmesinde $\chi^{2} /$ sd değerinin 2 ile 3 arasında olması yeterli uyumu, 2'den küçük olması ise iyi uyumu işaret etmektedir. Bir diğer uyum ölçütü olan RMSEA değerinin .05 ile .08 arasında olması modelin veri setiyle kabul edilebilir ve SRMR değerinin ise .05'ten az olması iyi uyumu ortaya koymaktadır (SchermellehEngel ve diğ., 2003). GFI, CFI, IFI ve TLI değerlerinin .90 ve üzerinde değer alması ise veri ile model arasındaki uyumun iyi olduğunu göstermektedir ( $\mathrm{Hu}$ ve Bentler, 1999). Ayrıca lisansüstü eğitim farkındalığının akademik başarı ile lisansüstü eğitim niyeti arasındaki ilişkide aracılık rolünü sınamak için YEM ile birlikte aracılığın istatistiksel olarak anlamlı olup olmadığını belirlemek amaciyla Bootstrapping yöntemi kullanılmıştır. Bootstrapping yöntemi, yapısal modeldeki doğrudan ve dolaylı etkilerin anlamlılığını test etmektedir (MacKinnon, 2008; Preacher ve Hayes, 2008).

\section{Bulgular}

$\mathrm{Bu}$ bölümde araştırmanın hipotezleri doğrultusunda elde edilen bulgular ve yorumlara yer verilmiştir.

\section{Korelasyon ve Betimsel İstatistikler}

Araştırmanın hipotezlerinin test edilmesinden önce çalışma kapsamında ele alınan değişkenler arasındaki ilişkilerin incelenmesi amaçlanmıştır. Değişkenlere ilişkin ortalama, standart sapma ve korelasyon analizi sonuçları Tablo 3 'te verilmiştir.

Tablo 3

Değişkenlere İlişkin Korelasyon Katsayıları ve Betimsel İstatistikler

\begin{tabular}{lccc}
\hline Değişkenler & $\mathbf{1}$ & $\mathbf{2}$ & $\mathbf{3}$ \\
\hline Lisansüstü eğitim farkındalı̆̆1 & - & $.21^{*}$ & $.39 * *$ \\
Akademik başarı & & - & $.36 * *$ \\
Lisansüstü eğitim niyeti & & 3.18 & - \\
\hline Ortalama & 1.12 & .98 & 3.32 \\
Standart sapma & & 1.01 \\
\hline * & & & \\
\hline
\end{tabular}

${ }^{*} p<.05, * * p<.001$

Korelasyon analizi sonuçlarında lisansüstü eğitim farkındalığı ile akademik başarı arasında pozitif yönlü anlamlı bir ilişki bulunmuştur $(r=.21 ; \mathrm{p}<.05)$. Ayrıca, lisansüstü eğitim farkındalığı ile lisansüstü eğitim niyeti arasında pozitif yönde anlamlı düzeyde bir ilişki ortaya çıkmıştır $(r=.39 ; \mathrm{p}<.001)$. Son olarak akademik başarı ile lisansüstü eğitim niyeti arasında pozitif yönde anlamlı bir ilişki belirlenmiştir $(\mathrm{r}=.36 ; \mathrm{p}<.001)$. Bu sonuçlar, söz konusu değişkenler arasında 
oluşturulan hipotetik modelin YEM analizi ile test edilmesini desteklemektedir (Kline, 2015).

\section{Hipotetik Modelin Test Edilmesi}

Ölçüm Modeli. Araştırmada YEM'in ilk aşamasında hipotetik modele ilişkin tüm değişkenleri kullanan bir ölçüm modeli sınanmıştır. Hipotetik model çalışmanın ikinci örneklem grubundan elde edilen veriler ile test edilmiştir. Ölçüm modeli AMOS 22.0 veri analizi programı aracilığıyla oluşturulmuş ve DFA ile test edilmiştir. Ölçüm modeli, ölçülen (gözlenen) değişkenler ile örtük (gizil) değişkenler arasındaki bağlantıları açıklamaktadır (Kline, 2015). Ölçüm modelinde akademik başarı puanı tek bir gizil değişken olarak belirlenmiştir. Lisansüstü eğitim farkındalığı gizil değiş̧keni altı adet gözlenen/gösterge değişken olarak tanımlanmıştır. Lisansüstü eğitim niyeti gizil değişkeni ise altı adet gözlenen değişken olarak belirlenmiştir. Böylece toplam üç gizil değişken ve on iki gözlenen değişken ile ölçüm modeli oluşturulmuştur. Yapılan DFA sonucunda akademik başarı, lisansüstü eğitim farkındalı̆̆ ve lisansüstü eğitim niyeti arasındaki ilişkileri ortaya koyan ölçüm modelinde tüm yol katsayıların anlamlı olduğu ve faktör yük değerlerinin .56 ile .86 arasında değiştiği bulunmuştur. Uyum indeksleri incelendiğinde $\left[\left(\chi^{2} / \mathrm{sd}=2.77, \mathrm{p}<\right.\right.$ $.000, \mathrm{RMSEA}=.051, \mathrm{GFI}=.93, \mathrm{CFI}=.94, \mathrm{TLI}=.91, \mathrm{IFI}=.93]$ ölçüm modelinin iyi uyum sağladığı ve doğrulandığı söylenebilir. Ölçüm modelinin doğrulanmasının ardından çalışmada oluşturulan hipotetik modelin incelenmesi aşamasına geçilmiştir.

Yapısal Model. Lisansüstü eğitim farkındalığının (aracı değişken) akademik başarı (bağımsız değişken) ile lisansüstü eğitim niyeti (bağımlı değişken) arasındaki ilişkiye aracılık edip etmediğini belirlemek için Baron ve Kenny'nin (1986) aracılık analizi prosedürü kullanılmıştır. Aracı bir değişkenin herhangi bir ilişki üzerinde iki şekilde aracılık rolü olabilir: Tam veya kısmi aracılık. Baron ve Kenny'a göre (1) bağımsız değişken(ler) ile bağımlı değişken anlamlı ilişkiye sahiptir; (2) bağımsız değişken(ler) ile aracı değişken anlamlı ilişkiye sahiptir; (3) aracı değişken ile bağımlı değişken anlamlı ilişkiye sahiptir, (4) aracı değiş̧ken bağımsız değişkenle birlikte modele eklendiğinde bağımsız değişkenin bağımlı değişken üzerindeki etkisi azalmaktadır. Analiz sonucunda, bağımsız değişkenin değerinde düşme olması ve aracı değişkenin de bağımsız değiş̧en üzerinde anlamlı bir etkisinin bulunması kısmi aracılık, ancak bu ilişkinin tamamen ortadan kalkması ise tam aracılık ilişkisini belirtmektedir.

Aracılık Analizi. Araştırma kapsamındaki değişkenler arasındaki doğrudan ve dolaylı etkiler YEM aracılığı ile incelenmiştir. Aracilık testinde dolaylı etkinin anlamlılığı ise bootstrapping işlemi kullanılarak test edilmiştir. Akademik başarı ile lisansüstü eğitim niyeti arasındaki ilişkide lisansüstü eğitim farkındalığının aracı rolüne ilişkin elde edilen sonuçlar Şekil 4 'te verilmiştir. 


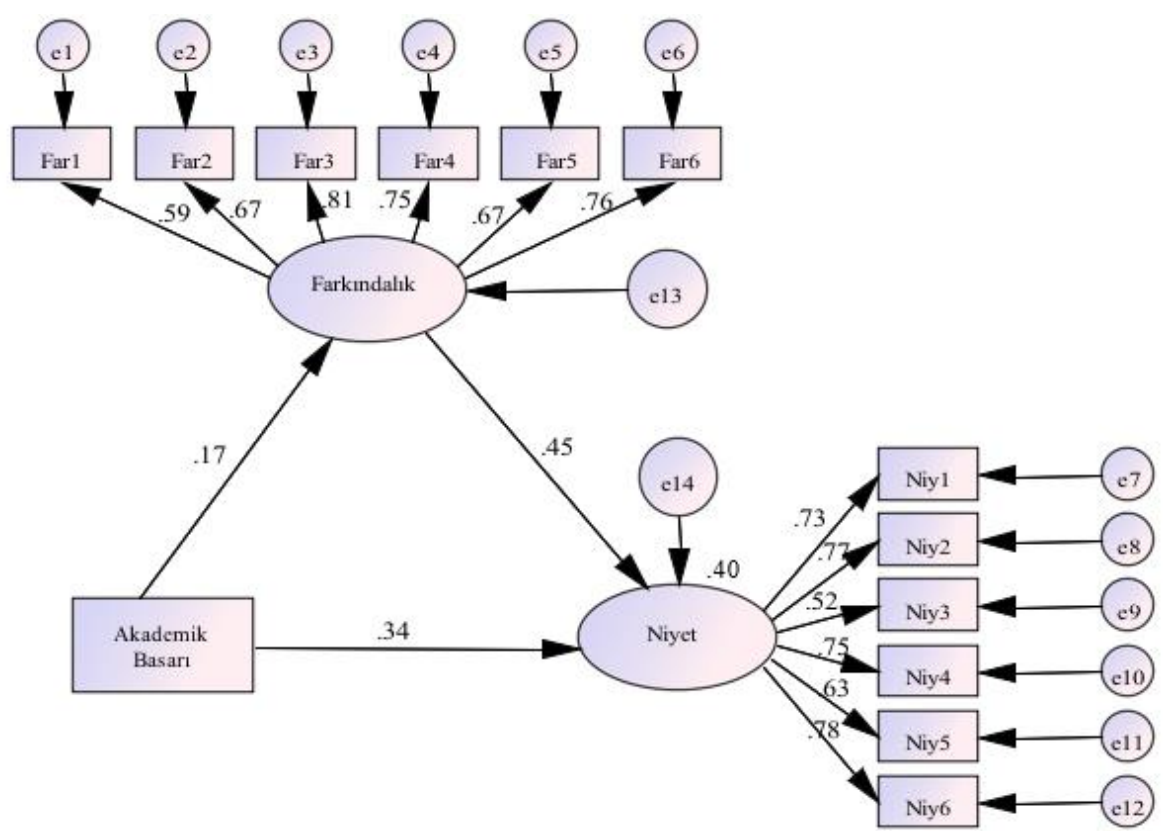

Şekil 4. Lisansüstü eğitim farkındalı̆̆ının aracılık rolünü gösteren model

Şekil 4'te görüldüğü gibi, aracı değişken olan lisansüstü eğitim farkındalığı lisansüstü eğitim niyetini $(\beta=.45, \mathrm{p}<.001)$ doğrudan yordamıştır. Ayrıca akademik başarının lisansüstü eğitim farkındalığını $(\beta=.17, p<.001)$ doğrudan yordadığı bulunmuştur. YEM analizi sonuçları ise akademik başarının lisansüstü eğitim niyetini hem doğrudan hem de $(\beta=.34, \mathrm{p}<.001)$ lisansüstü eğitim farkındalığı aracılığıyla dolaylı olarak yordadığını göstermiştir $(\beta=.10, \mathrm{p}<.05)$. Bu bulguya göre akademik başarı ile lisansüstü eğitim niyeti arasındaki ilişkide lisansüstü eğitim farkındalığı kısmi aracılık rolü oynamıştır. Bu adımdan sonra aracılık analizinde akademik başarı değişkeninin lisansüstü eğitim niyeti üzerindeki etkisinde yaşanan değişimin (regresyon katsayısındaki değişim) istatistiksel olarak anlamlı olup olmadığını belirlemek için bootstrapping yöntemi kullanılmıştır.

Bootstrapping analizi sonuçları, akademik başarının lisansüstü eğitim farkındalığı aracılı̆̆ıyla lisansüstü eğitim niyeti üzerinde dolaylı bir etkiye sahip olduğunu ve bu etkinin de anlamlı olduğunu göstermiştir ( $b=10.01 \% 95$ GA [.27, .44]). Analizler incelendiğinde akademik başarı ve lisansüstü eğitim farkındalığının birlikte lisansüstü eğitim niyetindeki toplam varyansın \%40'ını açıkladığı belirlenmiştir. Modelin bütünsel olarak anlamlılığı için YEM analizi çerçevesinde uyum indeksleri de incelenmiştir. Modelin uyum indekslerinin kabul edilebilir düzeyde $\left[\chi^{2} / \mathrm{sd}=2.45, \mathrm{CFI}=.95, \mathrm{GFI}=.93\right.$, $\left.\mathrm{RMSEA}=.06 ; \mathrm{IFI}=.91, \mathrm{TLI}=.92\right]$ olduğu söylenebilir (Schermelleh-Engel ve diğ., 2003). Elde edilen sonuçlar, araştırmanın 1, 2,3 ve 4. Hipotezlerini doğrulamıştır. YEM analizi sonucu oluşan doğrudan ve dolaylı 
etkilere yönelik katsayılar ve bu katsayılara ilişkin güven aralıkları Tablo 4'te sunulmuştur.

Tablo 4

Yapısal Eşitlik Modellemesi Analizi Sonuçları

\begin{tabular}{|c|c|c|c|c|c|}
\hline \multirow[t]{2}{*}{ Yol } & \multirow[t]{2}{*}{$\boldsymbol{\beta}$} & \multicolumn{2}{|c|}{$\begin{array}{c}\% 95 \text { GA } \\
\text { (2000 bootstraps) } \\
\end{array}$} & \multirow{2}{*}{$\begin{array}{l}\text { Standart } \\
\text { Hata }\end{array}$} & \multirow{2}{*}{$\mathbf{p}$} \\
\hline & & Alt & Üst & & \\
\hline \multicolumn{6}{|l|}{ Doğrudan Etki } \\
\hline $\mathrm{AB} \rightarrow \mathrm{LEF}$ & .17 & .43 & .75 & .69 & .010 \\
\hline $\mathrm{LEF} \rightarrow \mathrm{LEN}$ & .45 & .40 & .68 & .56 & .000 \\
\hline $\mathrm{AB} \rightarrow \mathrm{LEN}$ & .34 & .32 & .72 & .41 & .000 \\
\hline \multicolumn{6}{|l|}{ Dolaylı Etki } \\
\hline $\mathrm{AB} \rightarrow \mathrm{LEF} \rightarrow \mathrm{LEN}$ & 10 & .27 & .44 & .22 & .021 \\
\hline
\end{tabular}

\section{Tartışma, Sonuç ve Öneriler}

$\mathrm{Bu}$ araştırmada, henüz lisans programında öğrenim gören öğrencilerin lisans akademik başarısı ile lisansüstü eğitim niyetleri arasındaki ilişkide lisansüstü eğitime ilişkin farkındalık düzeylerinin aracılık rolü incelenmiştir. Bu amaç çerçevesinde değişkenler arasındaki ilişkide doğrudan ve dolaylı etkiler YEM aracılığıyla test edilmiştir. YEM analizi sonuçları, akademik başarının öğrencilerin lisansüstü eğitim alma niyetlerini doğrudan yordadığını göstermiştir. Alanyazında var olan araştırmalarla tutarlı olarak algılanan akademik başarı düzeyinin lisansüstü eğitime yönelik tutumun anlamlı bir yordayıcısı olduğu bulunmuştur (Büyükgöze ve Gelbal, 2016). Bununla birlikte araştırmacılar, üniversite öğrencilerinin akademik başarı ve akademik motivasyon düzeylerinin lisansüstü eğitim beklentilerini olumlu yönde yordadığını belirlemiştir (Pascarella, Cruce, Wolniak ve Blaich, 2004; Strayhorn 2006).

Akademik başarı ve kariyerle ilgili belirli konular arasında ilișkilerin bulunduğunu gösteren diğer çalışmalar incelendiğinde ise akademik başarının kariyer karar verme yetkinliği (Jadidian ve Dufy, 2012; Nauta, 2007; Yusupu, 2015), kariyer gelişimi (Yayla ve Bacanlı, 2011) ve kariyer olgunluğunu (Bae, 2017; Betz, Hammond ve Multon, 2005; Can ve Taylı, 2014; Sekmenli, 2000; Tekke ve Ghani, 2013) pozitif yönde yordadığı bulunmuştur. Negru-Subtirica ve Pop (2016) 1151 ergen ile yaptıkları çalışmada, kariyer karar verme yetkinliği yüksek olan öğrencilerin okulda daha iyi performans gösterme eğiliminde olduklarını ve yüksek akademik başarının öğrencilerin kariyer geleceğine bilinçli ve güvenli bakmasına yardımcı olduğunu saptamıştır. Benzer şekilde Davis, Amelink, Hirt ve Miyazaki (2012) yürüttükleri çalışmada, genel not ortalamasında bir birimlik artışın lisansüstü eğitim niyetlerini \%89.2 oranında artırdığını belirlemiştir. Bu sonuçlar 1şığında akademik 
başarının öğrencilerin lisansüstü eğitime başlama ile ilgili davranışsal niyetlerini (davranış eğilimi) biçimlendirmeye özendirdiği söylenebilir.

Kariyer gelişiminin güçlü bir bileşeni olarak tanımlanan akademik başarı, kariyer başarısı ile pozitif yönde ilişkilidir ve kariyer programlarının seçimi ve istihdam alanı açısından oldukça önemli bir ölçüt olarak değerlendirilir (Abele-Brehm ve Stief 2004; Bandura, Barbaranelli, Caprara ve Pastorelli, 2001; Lent, 2013). Araştırmacılar akademik başarının bireyin yetkinlik beklentilerini doğruladığını (Ör. Bir öğrenci okulundaki yüksek derecelerden dolayı güçlü matematik becerisine sahip olduğunu düşünebilir.), önceden var olan kariyer hedeflerini güçlendirdiğini (Ör. Yüksek lisans derecesinden sonra akademik personel olma isteği.) ve yeni meslek yollarının planlanmasına rehberlik ettiğini savunmuştur (Ör. Bir alanda kariyer planlama ve kariyer seçeneklerini düşünme.) (Schnabel, Alfeld, Eccles, Köller ve Baumert, 2002; Ünsal, 2014). Buna göre bu araştırmadan elde edilen bulguların alanyazındaki kuramsal açıklamalar ışığında tutarlı olduğu ve bireylerin gelecek için kariyer planlama etkinlikleri ekseninde akademik yetkinlik durumlarının önemli bir rol oynadığı anlaşılmaktadır (Bacanlı ve Sürücü, 2011; Cevher, 2015; Lent ve diğ., 2002; Savickas, 2013).

Araştırmada elde edilen bir diğer bulgu, lisansüstü eğitime ilişkin farkındalığın lisansüstü eğitime başlama ile ilgili niyeti pozitif yönde yordamasıdır. Başka bir deyişle lisansüstü programlar, lisansüstü eğitimin kariyer gelişimi açısından önemi hakkındaki farkındalığın üniversite öğrencilerinin lisans sonrası lisansüstü eğitime başlama konusundaki niyetlerini yönlendirmede etkili olduğu bulunmuştur. Elde edilen bu bulgu, lisansüstü eğitime yönelik farkındalığın üniversite öğrencilerinin kariyer kararında önemli bir rol oynadığını gösteren önceki araştırmalar ile uyumludur. Örneğin, Varhegyi (2009) çalışmasında lisansüstü eğitim farkındalığının üniversite öğrencilerinin kariyer kararını pozitif yönde etkilediğini ve öğrencilerin farkındalık düzeylerinin gelecekte akademik kariyer yapmayı destekleyen bir kavram olduğunu belirlemiştir. Benzer şekilde Varhegyi ve Jepsen'in (2009b) lisans öğrencilerinin lisansüstü eğitim alma durumlarını etkileyen etkenler üzerine yaptıkları çalışmada, üniversitelerin kariyer farkındalığı ve kariyer girişimine yönelik özendirici etkinliklerin öğrencilerin lisansüstü eğitim hedeflerini biçimlendirmede güçlü bir rol oynadığı ortaya çıkmıştır.

Lisansüstü eğitim farkındalığının öğrencilerin lisans sonrası kariyer niyetlerini olumlu yönde yordaması bulgusu, onların farklı beklenti veya gereksinimlerine (Ör. Kişisel gelişim, mesleki gelişim, kariyer olarak akademisyenlik vb.) yanıt veren kariyer tutumlarından kaynaklanması ile ilişkilendirilebilir (Neumann, 2003). Birincisi, henüz lisans derecesinin başında kendi alanında uzmanlaşmayı isteyen bir öğrenci, lisans sonrası kariyer geliştirme olanakları için bilgi edinmeye ve bu eğitimin gerekli koşulları için başarı elde etmeye çalışabilir. Mezuniyet sonrası bilgi ve becerilerini yenilemek, geliştirmek isteyen öğrenciler lisans derecelerini bir lisansüstü program aracılığıyla desteklemek için lisans sonrası eğitim olanakları hakkında bilgi edinmeye çalışabilir. Nitekim lisansüstü eğitim olanaklarına ilişkin farkındalık, 
lisansüstü eğitime başlama düşüncesinin önemli bir bileşenidir (Stewart ve Knowles, 1999).

Araştırmada elde edilen bulgular Sosyal Bilişsel Kariyer Kuramı çerçevesinde de yorumlanabilir (Lent ve diğ., 1994). Bu kurama göre kariyer farkındalığ 1 yüksek bireylerin kendilerini daha farklı kariyer seçenekleri için hazırlayabildikleri ve seçtikleri alanda devam etmede daha istekli ve çaba sergileyici oldukları belirtilmiştir. İkincisi, bir öğrenci lisans derecesinin alanında yeterli uzmanlaşmayı sağlamadığı kaygısına kapılacağı gibi işe alınma sürecindeki bekleme süresini firsata dönüştürme isteğinde olması nedeniyle mezuniyet sonrası bir lisansüstü programa başvurma düşüncesinde olabilir. Bu öğrencilerin lisansüstü deneyimlerin önemli bir kariyer fırsatı olduğunu ve bu eğitimin profesyonel ve mesleki yaşama başlamanın önemli bir adımı olduğunu düşündükleri varsayılır (Akoğlan-Kozak ve Dalkıranoğlu, 2013). Artan farkındalığın bir sonucu olarak öğrencilerden mezuniyet sonrası genel durum hakkında kariyer kararı vermeleri beklenir (Jepsen ve Neumann, 2010). Bu anlamda elde edilen bulgular bütüncül olarak değerlendirildiğinde lisans öğrencilerinin lisansüstü eğitime ilişkin farkındalık düzeylerine bakılarak onların gelecekte lisansüstü eğitim alma kararlarına ilişkin düşüncelerinin öngörülebileceği söylenebilir.

Araştırma bulguları lisansüstü eğitim farkındalığının akademik başarı ile lisansüstü eğitim niyeti arasındaki ilişside kısmi aracılık rolünü oynadığını göstermiştir. Elde edilen sonuçlara göre akademik başarının lisansüstü eğitim niyeti üzerindeki etkisi öğrencilerin lisansüstü eğitim ile ilgili farkındalık düzeylerine bağlı olarak değișebilmektedir. YEM analizi sonuçları, lisans sonrası programlar ve eğitim olanakları hakkındaki farkındalığın, öğrencilerin lisansüstü eğitime başlama konusundaki kariyer niyetlerini artırmada kilit nokta olabileceğini göstermiştir. Alanyazın incelendiğinde üniversite öğrencilerinin akademik başarısı, lisansüstü eğitim farkındalığı ve lisansüstü kariyer niyetleri arasındaki ilişkileri inceleyen herhangi bir çalışmaya rastlanmamıştır. Ancak konuyla ilgili olarak Malkin, Allen, Hambly ve Scott (1997), bireylerin gelecekle ilgili kariyer kararlarını vermek ve uygulamak için belirli bir akademik yetkinliğe ve farkındalık düzeyine sahip olmaları gerektiğini açıklaması, elde edilen bu bulguyu destekler niteliktedir. Bulgular, ayrıca lisans öğrencilerinin akademik başarı durumlarının lisansüstü eğitim ile ilgili farkındalık düzeyleri ile birlikte bir lisansüstü programa başvurma düşüncelerini olumlu yönde şekillendirdiğini göstermektedir. Başka bir deyişle, öğrenciler, planladığı lisansüstü kariyerin gerektirdiği nitelikleri sağlamaya çalışırken onların lisansüstü eğitim farkındalıklarının buna önemli derecede katkı sağladığı anlaşılmaktadır. Buna göre üniversite öğrencilerinin lisansüstü eğitim konusundaki farkındalık düzeylerinin gelecekte lisansüstü eğitime devam etmedeki olası niyetlerinde etkili olduğu söylenebilir.

Araştırmada elde edilen bu bulgu, farklı noktalarla açıklanabilir. Birincisi, lisansüstü eğitim çalışmalarına atfedilen bilgi ve farkındalık, akademik benlik saygısı ve kariyer gelişimini desteklemektedir (Porter ve Porter, 1991). Lisans döneminde 
akademik başarı artıkça, öğrencilerin lisansüstü eğitim seçenekleri hakkında bilgi edinmeleri ve bunlarla ilgilenme dereceleri de artmakta ve gelecekte kariyer planlamada lisansüstü eğitime devam etme düşüncesi ve isteğinde artış oluşabilmektedir. İkincisi, akademik başarı, firsat bilinci ve ek deneyimler bir araya geldiğinde bu durumun, öğrencilerin gelecekteki kariyerlerine yönelik düşünce yapılarını olumlu yönde şekillendirmesi olasıdır. Bu anlamda akademik başarı, lisans sonrası kariyer ve eğitim olanaklarına ilişskin farkındalık düzeyindeki bir artışın, gelecekte lisansüstü çalışmalara olan ilgi ve katılımı daha fazla oranda artıracağı söylenebilir (Artess ve Hooley, 2017; Patton ve Creed, 2001). Tüm bu bilgiler ışığında, akademik başarı ve lisans sonrası olanaklar ile ilgili artan bilincin bir sonucu olarak öğrencilerin mezuniyet sonrası lisansüstü eğitim alma konusunda olası niyetlerini ortaya koymaları beklenebilir.

Bütün araştırmalarda olduğu gibi bu araştırmanın da birtakım sınırlılıkları bulunmaktadır. Birincisi, araştırmanın verilerinin toplanmasında öz-bildirime dayalı ölçme araçlarının kullanılmasıdır. Araştırmada, öz-bildirime dayalı ölçme araçlarıyla verilerin toplanması nedeniyle çalışmadaki ilgili değişkenlerin yalnızca ölçme araçlarının kapsamınca açıklanabileceği ve katılımcıların sosyal istenirlikleri de göz önünde bulundurulmalıdır. Gelecekte yapılacak araştırmalarda bu sınırlıı̆ı̆n önüne geçilebilmesi için öz-bildirime dayalı ölçme araçlarının yanı sıra görüşme, gözlem gibi farklı yöntemlerin kullanılmasında yarar vardır. İkincisi, her ne kadar bu araştırmada nicel yöntemlerde kullanılabilecek etkili tekniklerden biri olan yapısal eşitlik modellemesi (Kline, 2015) kullanılmış olsa da tam olarak modelde kurulan yapısal yolların yönü üzerine yapılacak yorumlarda ve nedensel siralama yapmakta dikkatli davranmak gerekmektedir (Satıcı ve Deniz, 2019).

Araştırma kapsamında öne sürülen ve doğrulanan hipotetik modelde yer alan Akademik Başarı $\rightarrow$ Lisansüstü Eğitim Farkındalığı $\rightarrow$ Lisansüstü Eğitim Niyeti sıralamasını net olarak ortaya çıkarmak için boylamsal çalışmalara gereksinim duyulmaktadır. Üçüncüsü, araştırmada aracı değişken olarak lisansüstü eğitim farkındalığı ele alınmıştır. Gelecek araştırmalarda öğrencilerin lisansüstü eğitime devam etme konusunda karar vermelerinde farklı değişkenlerin (Ör. Lisansüstü eğitime ilişkin bilgi, akademik motivasyon, kariyer karar verme yetkinliği) aracı rolünü incelemeye ilişkin yeni çalışmalar yapılabilir. Dördüncüsü olarak örnekleme yöntemi ve katılımcı çeşitliliği ile ilgili sınırlılığın belirtilmesinde yarar vardır. Araştırmada farklı lisansüstü programlara sahip bir yükseköğretim kurumunun eğitim fakültesinde farklı programlarda öğrenim gören öğrencilerden veriler elde edilmiş olsa da farklı fakülte ve farklı bölümlerde öğrenim gören öğrencilerle yapılacak yeni araştırmalar bu çalışmada oluşturulan modelin sınanmasına katkı sağlayabilir ve elde edilen sonuçların genellenebilirlik düzeyini artırabilir. Son olarak, bu çalışmaya katılan öğrencilerin lisansüstü eğitim farkındalıkları ile lisansüstü eğitim niyetleri arasındaki ilişki cinsiyet, sınıf düzeyi ve sosyo-ekonomik düzeyi açısından incelenmemiştir. Bu nedenle gelecekteki araştırmalar katılımcıların bu değişkenler hakkındaki verilerini de modele dahil ederek değişkenler arasındaki açıklayıcı ve yordayıı ilişkileri inceleyebilir. 
Bütün bu sınırlılıklara karşın yapılan bu araştırma lisans akademik başarısı ile lisansüstü eğitim farkındalığı ve lisansüstü eğitim niyeti arasındaki ilişkiyi ele alan ilk çalışma olması açısından önemli olarak düşünülebilir. Araştırma, alanyazındaki önemli bir boşluğu ele almıştır. Elde edilen sonuçlar, lisans akademik başarısı ile lisans sonrası lisansüstü eğitime devam etme niyeti arasındaki ilişkileri açıklayan bir yapıya 1 şı tutmaktadır. Araştırmada doğrulanan modelden elde edilen bulgular, akademik başarı ile lisansüstü eğitim niyeti arasındaki ilişkiye aracılılık eden lisansüstü eğitim farkındalığının lisansüstü kariyer kararı üzerinde önemli bir role sahip olduğunu ortaya koyması açısından önemlidir. Akademik başarı ve lisansüstü eğitim farkındalığının öğrencilerin lisansüstü eğitime devam etme konusundaki düşüncelerini doğrudan etkilediği görülmüş ve araştırma sonuçları lisansüstü kariyer niyetinin öngörülmesinde farkındalık ve akademik başarı kavramlarına destek vermiştir. Bu bakımdan araştırma sonuçları, üniversite öğrencilerinin lisansüstü eğitim niyetlerini etkileyen birçok etkeni aydınlatmaktadır.

Birincisi, araştırma bulgularının üniversite öğrencilerinin lisans eğitimlerine yön vereceği ve mezuniyet sonrası lisansüstü eğitim niyetlerine katkı sağlayacağ beklenmektedir. Lisans sonrası firsatlara ilişkin farkındalık düzeyinin artması, lisansüstü çalışmalara olan ilgi ve katılımı artıracağı olası görünmektedir. Buna göre öğrencilerin kariyer planlama konusunda bilinçlendirilmesine daha fazla yardımcı olmak için üniversiteler, lisans sonrası programlar hakkında lisans öğrencileri için erken zamandan başlayarak ek firsatlar yaratabilir. Örneğin, üniversiteler toplumun gereksinimlerini daha doğru bir şekilde karşılamak amacıyla henüz lisans öğrenimi aşamasında olan öğrenciler için lisansüstü eğitim ile ilgili düzenli toplantılar yaparak, akademik kariyer programları geliştirerek ve uyarlayarak öğrencilerin gelecekteki kariyer düşüncelerini olumlu yönde etkilemeye katk1 sağlayabilir. Ayrıca üniversiteler kariyer danışma merkezi veya akademik odalar oluşturarak (Bilgilendirici, tanılayıcı, özendirici, düzenleyici, değerlendirici faaliyetler ışığında vb.) lisans sonrası eğitim olanakları, kariyer seçenekleri ve mesleki uzmanlık hakkında danışmanlık hizmeti vererek öğrencilerin kariyer kaygılarının giderilmesine yardımcı olabilir. Ancak lisansüstü eğitime katılım için bu hizmetin bütün öğrencilere duyurulması önemlidir. Buna ek olarak halka açık kariyer planlama günleri, web sitelerinde lisansüstü bilgilendirme formları, lisansüstü programlara ilişkin reklamlar, kısa tanıtım filmleri yine lisansüstü eğitime katılımı artırmada yapılacak örnek uygulamalar arasındadır. Ayrıca lisans öğrencilerinin lisansüstü eğitime katılımını artırmak için izleme ve iletişime dayalı bir akademik danışmanlık uygulaması yapılabilir. Bu durum üniversitelerde kariyer farkındalığına ilişkin güçlü bir imajın oluşturulmasına yardımcı olabilir.

Özendirmek amacıyla üstün derecede başarı gösteren lisansüstü öğrenciler ile yapılan röportajlar ve bilgilendirme oturumları da üniversitede birinci ve ikinci sınıfta eğitim gören öğrencilerin akademik başarı ve farkındalığını artırmak için akran rehberliğine dayalı kullanılan bir başka yol olabilir. Lisansüstü öğrenci sayısını artırmak isteyen üniversitelerin dönem başında var olan lisans öğrencilerinin kariyer potansiyelleri hakkında bilgi toplamaları, planlar yapmaları ve bu planları 
uygulamaya koymaları lisans sonrası eğitime başlama fikrinin erkenden öğrencilerin aklına yerleştirmesine yardımcı olabilir (Kelly ve Pulver, 2003). Böylece henüz lisans öğrenimi sürecinde olan öğrenciler mezun olduktan sonra lisansüstü derece programlarına başvurmak için gerekli koşulları sağlamak adına yeterli zamana sahip olacaktır. Sonuç olarak üniversitelerde, lisans öğrencilerinin lisansüstü eğitime ilişkin duygusal bağlılıklarının geliştirilmesi ve kariyer ilerlemesi için lisansüstü programlarının daha fazla tanıtımına yönelik uygulamalar ve çalışmalar gerçekleştirilebilir.

\section{Kaynakça}

Abele-Brehm, A. E., and Stief, M. (2004). Die Prognose des berufserfolgs von hochschulabsolventinnen und-absolventen: Befunde zur ersten und zweiten Erhebung der Erlanger Längsschnittstudie BELA-E. Zeitschrift für Arbeits-und Organisationspsychologie A and $O, 48(1), 4-16$.

Aitken, L., Currey, J., Marshall, A., and Elliott, D. (2008). Discrimination of educational outcomes between differing levels of critical care programmes by selected stakeholders in Australia: A mixed-method approach. Intensive and Critical Care Nursing, 24(2), 68-77.

Akoğlan-Kozak, M. ve Dalkıranoğlu, T. (2013). Mezun öğrencilerin kariyer algılamaları: Anadolu Üniversitesi örneği. Anadolu Üniversitesi Sosyal Bilimler Dergisi, 13(1), 41-52.

Alabaş, R., Kamer, S. T. ve Polat, Ü. (2012). Öğretmenlerin kariyer gelişimlerinde lisansüstü eğitim: tercih sebepleri ve süreçte karşılaştıkları sorunlar. $E$ international Journal of Educational Research, 3(4), 89-107.

Allen, B. M., and Zepeda, Y. (2007). From baccalaureate to the professoriate: Cooperating to increase access to graduate education. New Directions for Higher Education, 2007(138), 75-82.

Artess, J., and Hooley, T. (2017). Towards a new narrative of postgraduate career. R. Erwee, R. et al (Eds.), in Postgraduate Education in Higher Education (pp.1-19). Singapore: Springer.

Aşçı, Ö., Hazar, G., Kılıç, E. ve Korkmaz, A. (2015). Üniversite öğrencilerinde stres nedenlerinin ve stresle başa çıkma biçimlerinin belirlenmesi. Uşak Üniversitesi Sosyal Bilimler Dergisi, 8(4), 213-232.

Aydemir, S. ve Çam, Ş. (2015). Lisansüstü öğrencilerinin lisansüstü eğitimi almaya ilişkin görüşleri. Turkish Journal of Education, 4(4), 4-16.

Ayık, Y. Z., Özdemir, A. ve Yavuz, U. (2007). Lise türü ve mezuniyet başarısının kazanılan fakülte ile ilişkisinin veri madenciliği tekniği ile analizi. Atatürk Üniversitesi Sosyal Bilimler Enstitüsü Dergisi, 10(2), 441-454. 
Bacanlı, F. ve Sürücü, M. (2011). İlköğretim öğrencilerinin kariyer gelişimleri ile ebeveyne bağlanmaları arasındaki ilişkilerin incelenmesi. Türk Eğitim Bilimleri Dergisi, 9(4), 679-700.

Bae, S. M. (2017). An analysis of career maturity among Korean youths using latent growth modeling. School Psychology International, 38(4), 434-449.

Bandura, A. (1977). Self-efficacy: Toward a unifying theory of behavioral change. Psychological Review, 84(2), 191-215.

Bandura, A. (1991). Social cognitive theory of self-regulation. Organizational Behavior and Human Decision Processes, 50(2), 248-287.

Bandura, A. (1997). Self-efficacy: The exercise of control. New York, NY: Freeman.

Bandura, A., Barbaranelli, C., Caprara, G. V., and Pastorelli, C. (2001). Self-efficacy beliefs as shapers of children's aspirations and career trajectories. Child Development, 72(1), 187-206.

Baron, R. M., and Kenny, D. A. (1986). The moderator' mediator variable distinction in social psychological research: Conceptual, strategic, and statistical considerations. Journal of Personality and Social Psychology, 51(6), 1173-1182.

Battie, R., and Steelman, V. M. (2014). Accountability in nursing practice: Why it is important for patient safety. AORN Journal, 100(5), 537-541.

Bauer, K. W., and Bennett, J. S. (2003). Alumni perceptions used to assess undergraduate research experience. The Journal of Higher Education, 74(2), 210-230.

Bennett, P., and Turner, G. (2012). PTES 2012 National findings from the postgraduate taught experience survey. New York, NY: Higher Education Academy.

Betz, N. E., and Hackett, G. (1986). Applications of self-efficacy theory to understanding career choice behavior. Journal of Social and Clinical Psychology, 4, 279-289.

Betz, N. E., Hammond, M. S., and Multon, K. D. (2005). Reliability and validity of five-level response continua for the career decision self-efficacy scale. Journal of Career Assessment, 13(2), 131-149.

Bragt, C. A. C. V., Bakx, A. W. E. A., Teune, P. J., Bergen, T. C.M., and Croon, M. A. (2011). Why students withdraw or continue their educational careers: A closer look at differences in study approaches and personal reasons. Journal of Vocational Education and Training, 63(2), 217-233.

Briscoe, C. S. (2002). The development and validation of an adult students' career needs questionnaire (Unpublished doctoral dissertation), University of 
Tennessee,

USA.

Erişim

http://search.proquest.com/docview/305472853?accountid=12154. 305472853.

Browne, M. W., and Cudeck, R. (1993). Alternative ways of assessing model fit. K. A. Bollen and J. S. Long (Eds), in Testing structural equation models (pp. 136162). London: Sage.

Buchanan, F. R., Kim, K. H., and Basham, R. (2007). Career orientations of business master's students as compared to social work students: Further inquiry into the value of graduate education. Career Development International, 12(3), 282-303.

Büyükgöze, H. ve Gelbal, S. (2016). Lisansüstü eğitime yönelik tutumda proaktif kişilik ve akademik kontrol odağının rolü., K. Beycioğlu, N. Özer, D. Koşar ve İ. Şahin (Ed.), Eğitim yönetimi araştırmaları içinde (ss. 91-103). Ankara: Pegem Akademi Yayıncılık.

Büyükgöze-Kavas, A. (2011). Testing a model of career indecision among university students based on social cognitive career theory. (Yayımlanmamış doktora tezi). Orta Doğu Teknik Üniversitesi Sosyal Bilimler Enstitüsü, Ankara.

Büyüköztürk, Ş. (2014). Sosyal bilimler için veri analizi el kitabl: Ístatistik, araştırma deseni SPSS uygulamalarl ve yorum (20. Basım). Ankara: Pegem Akademi Yayıncilık.

Byrne, M. B. (2010). Structural equation modeling with Amos: Basic concepts, applications, and programming (2nd ed.). New York, NY: Taylor and Francis.

Can, A. (2014). SPSS ile bilimsel araştırma sürecinde nicel veri analizi. Ankara: Pegem Akademi Yayıncılık.

Can, A. ve Taylı, A. (2014). Ortaokul öğrencilerinin kariyer gelişimlerinin incelenmesi. Abant İzzet Baysal Üniversitesi Eğitim Fakültesi Dergisi, 14(2), 321-346.

Cevher, E. (2015). Üniversitelerde kariyer planlama faaliyetleri ekseninde kariyer merkezlerine yönelik bir araştırma. Karabük Üniversitesi Sosyal Bilimler Enstitüsü Dergisi, 5(2),164-177.

Chaboyer, W., and Retsas, A. (1996). Critical care graduate diploma: Nursing students' needs identified in evaluation. Australian Critical Care, 9(1), 10-13.

Cole, D. A. (1987). Utility of confirmatory factor analysis in test validation research. Journal of Consulting and Clinical Psychology, 55(4), 584-594.

Corominas, C. E., Saurina, C., and Vilar, E. (2010). The match between university education and graduate labour market outcomes (Education-Job Match). An analysis of three graduate cohorts in Catalonia. Studies on higher education and graduate employment. Girona University. http://www.aqu.cat/doc/doc_12987231_1.pdf adresinden erişilmiştir. 
Cotterill-Walker, S. M. (2012). Where is the evidence that master's level nursing education makes a difference to patient care? A literature review. Nurse Education Today, 32, 57- 64.

Cragg, C. E., and Andrusyszyn, M. (2004). Outcomes of master's education in nursing. International Journal of Nursing Education, 1(1), 1-18.

Creed, P., Patton, W., and Prideaux, L. A. (2006). Causal relationship between career indecision and career decision-making self-efficacy: A longitudinal cross-lagged analysis. Journal of Career Development, 33(1), 47-65.

Çokluk, Ö., Şekercioğlu, G. ve Büyüköztürk, Ş. (2016). Sosyal bilimler için çok değişkenli istatistik: SPSS ve LISREL uygulamalart. Ankara: Pegem Akademi Yayıncilık.

Çoruk, A., Çağatay, Ş. M. ve Öztürk, H. (2016). Lisansüstü eğitimde kayıt ve devam sorunları. Uşak Üniversitesi Sosyal Bilimler Dergisi, 9(1), 165-178.

Davis, S. D., Amelink, C., Hirt, J. B., and Miyazaki, Y. (2012). Women's educational opportunities: Factors that influence their graduate school aspirations. NASPA Journal about Women in Higher Education, 5(2), 141-165.

DeVellis, R. (2003). Scale development: theory and applications (2nd ed.). Thousand Oaks, CA: Sage.

Erkılıç, T. A. (2007). Öğretmen adaylarının lisansüstü eğitim istekliliklerini etkileyen etmenler (Eskişehir örneği). GAU Journal of Social and Applied Sciences, 3(5), 46-72.

Ertem, H. Y., Engin-Demir, C. ve Gökalp, G. (2017, Mayıs). Öğretmen adaylarının kariyer planlaması: Bir ihtiyaç analizi çalışması. 12. Uluslararası Eğitim Yönetimi Kongresi. Başkent Üniversitesi, Ankara.

Field, A. (2009). Discovering statistics using SPSS. (3rd ed.). London: Sage.

Fornell, C., and Larcker, D.F. (1981). Evaluating structural equation models with un observable variables and measurement error. Journal of Marketing Research, $18(1), 39-50$

Gardner, S.K., and Barnes, B.J. (2007). Graduate student involvement: socialization for the professional role. Journal of College Student Development, 48(4), 369387.

Gati, I., Kraus, M., and Osipow, S. (1996). A taxonomy of difficulties in career decision making. Journal of Counseling Psychology, 43(4), 510-526.

Gianakos, I. (1999). Patterns of career choice and career decision-making selfefficacy. Journal of Vocational Behavior, 54(2), 244-258.

GradSchools.com. (2019). What is a doctorate degree vs a $\mathrm{PhD}$ degree? https://www.gradschools.com/doctorate adresinden erişilmiştir. 
Hair, J. J., Black, W. C., Babin, B. J., Anderson, R. E., and Tatham, R. L. (2006). Multivariate data analysis. New York, NY: Upper Saddle River.

Harackiewicz, J. M., Barron, K. E., Tauer, J. M., and Elliot, A. J. (2002). Predicting success in college: A longitudinal study of achievement goals and ability measures as predictors of interest and performance from freshman year through graduation. Journal of Educational Psychology, 94, 562-575.

Hartung, P. J., Porfeli, E. J., and Vondracek, F. W. (2005). Child vocational development: A review and reconsideration. Journal of Vocational Behavior, 66(3), 385-419.

Hathaway, R. S., Nagda, B. R. A., and Gregerman, S. R. (2002). The relationship of undergraduate research participation to graduate and professional education pursuit: an empirical study. Journal of College Student Development, 43(5), 614631.

Hayes, A. F. (2013). Introduction to mediation, moderation, and conditional process analysis: A regression-based approach. New York, NY: Guilford.

Hu, L. T., and Bentler, P. M. (1999). Cutoff criteria for fit indexes in covariance structure analysis: Conventional criteria versus new alternatives. Structural equation modeling: A Multidisciplinary Journal, 6(1), 1-55.

İlter, İ. (2019). Lisansüstü Eğitime Yönelik Tutum Ölçeği’nin Türk kültürüne uyarlanması: Geçerlik ve güvenirlik çalışması. Illkögretim Online, 18(1), 125 156.

Jadidian, A., and Duffy, R. D. (2012). Work volition, career decision self-efficacy, and academic satisfaction: An examination of mediators and moderators. Journal of Career Assessment, 20(2), 154-165.

Jepsen, D. M., and Neumann, R. (2010). Undergraduate student intentions for postgraduate study. Journal of Higher Education Policy and Management, 32(5), 455-466.

Jepsen, D. M., and Varhegyi, M. M. (2011). Awareness, knowledge and intentions for postgraduate study. Journal of Higher Education Policy and Management, 33(6), 605-617.

Jepsen, D.M., and Neumann, R. (2008, April). The influence of a single semester of 3rd year study on students' intentions for a postgraduate research degree - what difference does a semester make? Paper presented at the Quality in Postgraduate Research Conference, Adelaide.

Johnson, A., and Copnell, B. (2002). Benefits and barriers for registered nurses undertaking post-graduate diplomas in pediatric nursing. Nurse Education Today, 22(2), 118-127. 
Karadaş, A., Duran, S., ve Kaynak, S. (2017). Hemşirelik öğrencilerinin kariyer planlamaya yönelik görüşlerinin belirlenmesi. SDÜ Sağlık Bilimleri Dergisi, $8(1), 1-8$.

Karakul, A. K. ve Karakütük, K. (2014). Lisansüstü öğretime öğrenci seçiminde kullanılan ölçütlere ilişkin öğretim elemanlarının görüşleri. Ankara Üniversitesi Ĕ̈itim Bilimleri Fakültesi Dergisi, 47(2), 179-200.

Karakütük, K. (2000). Öğretmenlerin lisansüstü öğretimi konusunda yönetici ve öğretmen görüşleri. Buca Eğitim Fakültesi Dergisi, 12, 193-209.

Karakütük, K. (2002). Öğretim üyesi ve bilim insanı yetiştirme-lisansüstü öğretimin planlanması (2. Basım). Ankara: Anı Yayıncılık.

Karakütük, K. (2009). Türkiye lisansüstü öğretim sistemi. K. Karakütük (Ed.), Lisansüstü ögretim sistemleri içinde (ss. 521-545). Ankara: Pegem Akademi Yayınc1lık.

Kelly, K. R., and Pulver, C. A. (2003). Refining measurement of career indecision types: A validity study. Journal of Counseling and Development, 81(4), 445-454.

Kerry, T. (2012). Meeting the challenges of change in postgraduate education. New York, NY: Continuum International Publishing Group.

Kim, T., Chang, J. Y., Myung, S. J., Chang, Y., Park, K. D., Park, W. B., and Shin, C. S. (2016). Predictors of undergraduate and postgraduate clinical performance: A longitudinal cohort study. Journal of Surgical Education, 73(4), 715-720.

Kline, R. B. (2015). Principles and practice of structural equation modeling (4th ed.). New York, NY: Guilford.

Kuzgun, Y. (2004). Meslek rehberligi ve danışmanlıgına giriş. Ankara: Nobel Yayınc1lik.

Leman, J. (2015). What do taught postgraduates want? The Postgraduate taught experience survey 2015? New York, NY: Higher Education Academy.

Lent, R. W. (2005). A social cognitive view of career development and counseling. S.D. Brown, and R.W. Lent (Eds.), in Career development and counseling: Putting theory and research to work (pp. 101-127). Hoboken, New Jersey, NJ: John Wiley.

Lent, R. W. (2013). Social cognitive career theory. S. D. Brown, and R. W. Lent (Eds.), in Career development and counseling: Putting theory and research to work (2nd ed.). (pp. 115-146). Hoboken, New Jersey, NJ: John Wiley.

Lent, R. W., Brown, S. D., and Hackett, G. (1994). Toward a unifying social cognitive theory of career and academic interest, choice, and performance. Journal of Vocational Behavior, 45(1), 79-122. 
Lent, R. W., Brown, S. D., and Hackett, G. (2002). Social cognitive career theory. D. Brown (Ed.), in Career choice and development (pp. 255-311). San Francisco: Jossey-Bass.

Leung, S. A., Hou, Z. J., Gati, I., and Li, X. (2011). Effects of parental expectations and cultural-values orientation on career decision-making difficulties of Chinese university students. Journal of Vocational Behavior, 78(1), 11-20.

Lindley, J., and Machin, S. (2013). The postgraduate premium: revisiting trends in social mobility and educational inequalities in Britain and America. London: The Sutton Trust.

Ling-Yi, Z. (2006). American and Chinese college students' anticipations of their postgraduate education, career, and future family roles. Sex Roles, 55, 95-110.

Lopatto, D. (2004). Survey of undergraduate research experiences (SURE): First Findings. Cell Biology Education, 3(4), 270-277.

MacKinnon, D. P. (2008). Multivariate applications series. Introduction to statistical mediation analysis. New York, NY: Taylor and Francis.

Malkin, J., Allen, A., Hambly, L., and Scott, F. (1997). Rational career planning, perspectives on career planning, occasional papers in careers guidance. No. 1, Trent University Nottingham.

Mann, L., Harmoni, R., and Power, C. (1989). Adolescent decision-making: The development of competence. Journal of Adolescence, 12(3), 265-278.

Martens, M.P., and Felissa K.L. (1998). Promoting life career development in the student athlete: How can career centers help? Journal of Career Development, 25(2), 123-134.

Mellors-Bourne, R., Hooley, T., and Marriott, J. (2014). Understanding how people choose to pursue taught postgraduate study: Report to HEFCE by CRAC and iCeGS.

Meydan, C. H. ve Şeşen, H. (2015). Yapısal eşitlik modellemesi AMOS uygulaması. (2. Basım). Ankara: Detay Yayıncılık.

Nas, S., Peyman, D. ve Arat, Ö. G. (2016). Bireylerin yüksek lisans yapma nedenleri üzerine bir araştırma. Dokuz Eylül Üniversitesi Sosyal Bilimler Enstitüsü Dergisi, 18(4), 571-599.

Nauta, M. M. (2007). Assessing college students' satisfaction with their academic majors. Journal of Career Assessment, 15(4), 446-462.

Negru-Subtirica, O., and Pop, E. I. (2016). Longitudinal links between career adaptability and academic achievement in adolescence. Journal of Vocational Behavior, 93, 163-170. 
Neumann, R. (2003). The doctoral education experience. Canberra: Department of Education, Science and Training. Canberra. Australian Government Publishing Service.

Ng, L.C. H. (2016). Exploring registered nurses' attitudes to postgraduate education for specialty practice in Australia. (Unpublished dissertation thesis). University of Queensland: Australia.

Niles, S. G., Erford, B. T., Hunt, B., and Watts, R. H. (1997). Decision-making styles and career development in college students. Journal of College Student Development, 38(5), 479-88.

O'Grady, A., and Cottle, V. (Eds.). (2015). Exploring education at postgraduate level: Policy, theory and practice. Nottingham, Routledge.

Ohnishi, S., and Ford, J. H. (2015). Student seminar program for improving academic presentation skills for $\mathrm{PhD}$ students in science: The effect of language background on outcome. International Journal for Researcher Development, $6(1), 57-76$

Özdamar, K. (1999). Paket programlar ile istatistiksel veri analizi. Eskişehir: Kaan Kitabevi.

Pallant, J. (2001). SPSS survival manual. A Step-by-step guide to data analysis using SPSS for Windows. Philadelphia, PA: Open University Press.

Pascarella, E. T., Cruce, T. M., Wolniak, G. C., and Blaich, C. F. (2004). Do liberal arts colleges really foster good practices in undergraduate education? Journal of College Student Development, 45(1), 57-74.

Patton, W., and Creed, P. (2001). Developmental issues in career maturity and career decision status. The Career Development Quarterly, 49(4), 336-351.

Pelletier, D., Donoghue, J., and Duffield, C. (2003). Australian nurses' perception of the impact of their postgraduate studies on their patient care activities. Nurse Education Today, 23(6), 434-442.

Pires, A. L. D. O. (2009). Higher education and adult motivations towards lifelong learning. European Journal of Vocational Training, 46(1), 129-150.

Plant, E. A., Ericsson, K. A., Hill, L., and Asberg, K. (2005). Why study time does not predict grade point average across college students: Implications of deliberate practice for academic performance. Contemporary Educational Psychology, 30(1), 96-116.

Poropat, A.E. (2009). A meta-analysis of the five-factor model of personality and academic performance. Psychological Bulletin, 135(2), 322-338.

Porter, R. T., and Porter, M. J. (1991) Career development: Our professional responsibility. Journal of Professional Nursing, 7(4), 208-212. 
Preacher, K. J., and Hayes, A. F. (2008). Asymptotic and resampling strategies for assessing and comparing indirect effects in multiple mediator models. Behavior Research Methods, 40(3), 879-891.

Purcell, K., Elias, P., Atfield, G., Behle, H., Ellison, R., Luchinsaya, D., Snape, J., Conaghan, L., and Tzanakou, C. (2012). Future track stage 4: Transitions into employment, further study and other outcomes. Manchester: Higher Education Careers Services Unit.

Richardson, M., Abraham, C., and Bond, R. (2012). Psychological correlates of university students' academic performance: A systematic review and metaanalysis. Psychological Bulletin, 138(2), 353-387.

Robbins, S. B. (1985). Validity estimates for the career decision-making self-efficacy scale. Measurement and Evaluation in Counseling and Development, 18(2), 64 71.

Sangganjanavanich, V.F., and Magnuson, S. (2011). Using sand trays and miniature figures to facilitate career decision making. The Career Development Quarterly, 59(3), 264-273.

Satıcı, S. A. ve Deniz, M. E. (2019). Ergenlerin kendilik algıları ve okul doyumu: öznel zindeliğin aracılık rolünün değerlendirilmesi. Eğitim ve Bilim, 44(197), 367-381.

Savickas, M.L. (2013). Career construction theory and practice. R.W. Lent, and S.D. Brown (Eds.), in Career development and counseling: Putting theory and research to work (pp. 147-183) (2nd ed.). Hoboken, New Jersey, NJ: John Wiley.

Scarbecz, M., and Ross, J. A. (2007). The relationship between gender and postgraduate aspirations among first-and fourth-year students at public dental schools: a longitudinal analysis. Journal of Dental Education, 71(6), 797-809.

Schermelleh-Engel, K., Moosbrugger, H., and Müller, H. (2003). Evaluating the fit of structural equation models: Tests of significance and descriptive goodness-of-fit measures. Methods of Psychological Research Online, 8(2), 23-74.

Schnabel, K. U., Alfeld, C., Eccles, J. S., Köller, O., and Baumert, J. (2002). Parental influence on students' educational choices in the United States and Germany: Different ramifications-same effect? Journal of Vocational Behavior, 60(2), 178198.

Schumacker, R.E., and Lomax, R.G. (2010). A beginner's guide to structural equation modeling (3rd ed.). New York, NY: Taylor ve Francis.

Sekmenli, T. (2000). Lise 1. sınıf öğrencilerinin mesleki olgunluk düzeyleri ile sürekli kaygı düzeylerinin bazı değişkenler açısından incelenmesi. (Yayımlanmamış yüksek lisans tezi). İnönü Üniversitesi Sosyal Bilimler Enstitüsü, Malatya. 
Sevinç, B. (2001). Türkiye'de lisansüstü eğitim uygulamaları, sorunlar ve uygulamalar. Dokuz Eylül Üniversitesi Eğitim Fakültesi Dergisi, 34(1), 25-40.

Sikora, J., and Pokropek A. (2011). Gendered career expectations of students perspectives from PISA 2006. OECD Education Working Papers, No. 57 Paris: OECD Publishers.

Stewart, J., and Knowles, V. (1999). The changing nature of graduate careers. Career Development International, 4(7), 370-383.

Strayhorn, T. L. (2006). Factors influencing the academic achievement of firstgeneration college students. NASPA Journal, 43(4), 1278-1307.

Strenze, T. (2007). Intelligence and socioeconomic success: A meta-analytic review of longitudinal research. Intelligence, 35(5), 401-426.

Stuart, M., Lido, C., Morgan, M., Solomon, L., and Akroyd, K. (2008). Widening participation to postgraduate study: Decisions, deterrents and creating success. New York, NY: Higher Education Academy.

Şimşek, Ö. F. (2007). Yapısal eşitlik modellemesine giriş; Temel ilkeler ve LISREL uygulamaları. Ankara: Ekinoks Yayıncılık.

Tabachnick, B. G., and Fidell, L. S. (2007). Using multivariate statistics (5th ed.). Upper Saddle River, NJ: Pearson, Allyn and Bacon.

Tekke, M., and Ghani, M. F. A. (2013). Examining the level of career maturity among Asian foreign students in public university: Gender and academic achievement. Hope Journal of Pakistan, 1(1), 101-12.

Thompson, B. (2004). Exploratory and confirmatory factor analysis: Understanding concepts and applications. Washington, DC, US: American Psychological Association.

Tonbul, Y. (2017). Sosyal bilimler enstitülerinin lisansüstü eğitimin niteliğini artırmadaki rolü. Yükseköğretim ve Bilim Dergisi, 7(1), 150-162.

Toprak, M. ve Erdoğan, A. (2013). Lisansüstü eğitimde Avrupa yaklaşımı. VI. Ulusal Lisansüstü Eğitim Sempozyumu, Bildiriler Kitabı. Sakarya Üniversitesi Eğitim Bilimleri Enstitüsü Yayınları, Yayın No 95, 10-36.

Tosun, A. (2001). Bilim adamı yetiştirme: Lisansüstü eğitim. Ankara: TÜBA Yayıncilık.

Ünal, Ç. ve İlter, İ. (2010). Sınıf öğretmeni adaylarının lisansüstü eğitime olan tutumları (Fırat, Erzincan ve İnönü Üniversitesi sınıf öğretmenliği ABD örneği). Atatürk Üniversitesi Sosyal Bilimler Enstitüsü Dergisi, 14(2), 147-164.

Ünsal, P. (2014). Kariyer gelişim kuramları ve kariyer danışmanlı̆̆ı. Ankara: Nobel Yayıncilık. 
Varhegyi, M. M. (2009). Career certainty and career decision-making self-efficacy in postgraduate study intentions. (Unpublished doctoral dissertation). Macquarie University. Australia.

Varhegyi, M. M., and Jepsen, D. M. (2009a, June-July). Undergraduate student aspirations, awareness and knowledge of postgraduate study options: A preliminary, qualitative investigation. Proceedings of the 17th Annual Conference of the International Employment Relations Association (IERA), Mahidol University, Bangkok, Thailand.

Varhegyi, M.M., and Jepsen, D.M. (2009b, December).Undergraduate student aspirations, awareness and knowledge of postgraduate study options: A crossinstitutional examination. Paper presented at the 23rd Annual Australian and New Zealand Academy of Management Conference, Melbourne, Australia.

Wakeling, P. (2009). Social class and access to postgraduate education in the UK: A sociological analysis. (Unpublished doctoral thesis). University of Manchester.

Watson, M.B., and Stead, G.B. (1997). Are career mature students more committed to the care choice process? Journal of Industrial Psychology, 23(3), 20-21.

Wisker, G. (2007). The postgraduate research handbook: Succeed with your MA, MPhil, EdD and PhD. New York, NY: Palgrave and Macmillan.

Yang, Y., and Green, S.B. (2011). Coefficient Alpha: A reliability coefficient for the 21st century? Journal of Psychoeducational Assessment, 29(4), 377-392.

Yayla, A. ve Bacanlı, F. (2011). İlköğretim 8. sınıf öğrencilerinin kariyer gelişimleri ile karar verme stilleri arasındaki ilişkilerin incelenmesi. Illkögretim Online, 10(3), 1148-1159.

Yusupu, R. (2015). Üniversite ögrrencilerinde kariyer kararlart ile mükemmeliyetçilik, ögrenme motivasyonu ve akademik başarı arasındaki ilişkiler. (Yayımlanmamış yüksek lisans tezi). Dokuz Eylül Üniversitesi Eğitim Bilimleri Enstitüsü, İzmir.

Yükseköğretim Kurulu (YÖK). (2016). Lisansüstü eğitim ve öğretim yönetmeliği. http://www.yok.gov.tr adresinden erişilmiştir. 


\section{Relationships between Academic Achievement, Awareness about the Postgraduate Study and Postgraduate Study Intentions ${ }^{1}$}

\begin{tabular}{cccc}
\hline ARTICLE TYPE & Received Date & Accepted Date & Published Date \\
Research Article & 06.26 .2019 & 03.27 .2020 & 04.01 .2020 \\
\hline \multicolumn{4}{c}{ İlhan İlter iD ${ }^{2}$} \\
University of Kahramanmaraş Sutcu Imam
\end{tabular}

\section{Abstract}

This study aimed to examine the mediating role of awareness about Postgraduate study (PG) in the relationship between undergraduate academic achievement, and the intentions to pursue a PG study. In addition, it was tested whether academic achievement and awareness about PG study predict intentions to PG study. Within the scope of this aim, first of all, the PG study intention and awareness about PG study instrument have been developed for validity and reliability studies. The participants consisted of 415 undergraduate students studying in different grades and programs in a faculty of education of a state university in Turkey. In the analysis of the data, exploratory factor analysis, confirmatory factor analysis, correlation analysis, and structural equation modeling (SEM) were used. The results of the analysis showed that academic achievement directly predicted the awareness about PG study and the PG study intention. The results of SEM analysis indicated that awareness about PG study played a mediating role in the relationship between academic achievement and PG study intention. This study yielded two findings: first, the academic achievement of undergraduate students and their level of awareness about PG study options play an important role in predicting intentions to pursue a PG study. Second, the awareness of PG study can be a key point in predicting the intentions of undergraduate students to pursue postgraduate research studies. The results suggest that regular awareness-raising workshops and promotions based on PG study options and programs for current undergraduate students for awareness raising in PG study may serve to improve students' current conditions early and positively shape their thoughts and intentions about their future career goals.

Keywords: Postgraduate study, career development, academic achievement, structural equation modeling, bootstrapping method.

\footnotetext{
${ }^{1}$ Some of the data in this study was presented at the 8th International Social Studies Education Symposium. ${ }^{2}$ Corresponding Author: Associate Prof. Dr., Faculty Department of Educational Social Studies Education Departmant, E-mail:iilter@ksu.edu.tr, https://orcid.org/0000-0002-4411-200X
} 


\section{Purpose and Significance}

In this study, a model based on explaining the mediating role of awareness about postgraduate study in the relationship between academic achievement and intention to postgraduate (PG) study, based on the theoretical explanations in the literature and the results of the previous research, and the mediating role on the developed model were examined. It was hypothesized that the academic achievement of undergraduate students positively predicted their intentions to start their postgraduate education together with their level of awareness about postgraduate study. Therefore, it is thought that awareness about the postgraduate study will mediate the relationship between academic achievement and postgraduate intention. The reason why the academic achievement variable was included in this study was that academic achievement was considered as a performance indicator directly related to the choice of professional success and job opportunities (Plant, Ericsson, Hill and Asberg, 2005; Strenze, 2007). In addition, it is a significant criterion for students, universities and even employers (Richardson, Abraham and Bond, 2012). Indeed, it is assumed that the individual's career control and career goal are guided by their academic achievement (Ayık, Özdemir and Yavuz, 2007; Büyükgöze-Kavas, 2011; Gianakos, 1999; Niles, Erford, Hunt and Watts, 1997). This is because academic achievement has a strong impact on students' professional ways and career goals in transition to adulthood (Poropat, 2009). According to Bandura (1991), the higher the perceived self-efficacy and self-esteem of achievement, the more ambitious challenges are pursued and greater achievement goals are set. Social cognitive career theory, which was developed on the basis of Bandura's Social Cognitive Theory, emphasizes the importance of competence expectancy, which is considered as cognitive status in career development process (Lent, Brown and Hackett, 1994). The expectation of competence defines beliefs that one can achieve different performances or achieve goals (Lent, 2005). In social cognitive career theory, individuals with strong academic competence expectations have more career options, and these choices have a direct relationship with their interests and abilities. It is considered that they can prepare themselves for different career options and they want to specialize in their chosen field (Lent, Brown and Hackett, 2002). As a result, academic achievement increases the level of competence in career decision-making (Bandura, 1977, 1997). Thus, it helps the individual to draw career paths by making the individual more competent in making career-related decisions. Research has confirmed that academic grade point average (GPA) is an effective and reliable performance indicator for participation in both undergraduate and postgraduate study (Corominas, Saurina and Villar 2010; Karakul and Karakütük, 2014; Kim et al., 2016; Scarbecz and Ross, 2007). When the literature review is examined, previous research on the factors affecting the decision of undergraduate students to take postgraduate study are quite limited (Aydemir and Çam, 2015; Çoruk, Çağatay and Öztürk, 2016; Ünal and İlter, 2010). Academic achievement of students as a result of investigations carried out in Turkey, which examines the relationship between awareness of postgraduate study and postgraduate career decision has not addressed just. This is thought to be due to the lack of a special 
psychometric instrument that measures the level of awareness of PG study of undergraduate students and their intention to continue a PG study. Within the framework of all these requirements, in this study, instruments based on determining the intention of students who are currently studying at an undergraduate level to continue their postgraduate education and their awareness levels for postgraduate education have been developed and the effects of the related variables on each other have been examined through structural equation modeling. For this reason, this study aimed to examine the impact of the academic achievement and awareness about PG study on intentions to pursue postgraduate studies among undergraduate students, thus addressing an important gap in the relevant literature. Identifying the possible variables that affect the decision of postgraduate education may be important for students who are currently in an undergraduate degree because understanding these factors can help ensure that they have sufficient awareness of their personal competencies to make informed educational and professional choices about their future. In addition, academic achievement, career awareness and decision-making structures are thought to be important in conceptualizing postgraduate career. Finding the explanatory and predictive relationships by integrating the variables of academic achievement, awareness about PG study, and intention of PG study together in a study can help to better understand the process involved in shaping the PG study objectives of undergraduate students. In this respect, it would be appropriate to conduct a study based on the examination of relevant variables affecting the decision to continue a postgraduate research study.

The hypotheses of the model created in this study, which was conducted in order to investigate the relationships between academic achievement, awareness about postgraduate education and intention to postgraduate education, are as follows:

Hypothesis 1. Academic achievement is a significant predictor of awareness about postgraduate study among current undergraduate students.

Hypothesis 2. Awareness about postgraduate study is a significant predictor of the intentions to pursue postgraduate study.

Hypothesis 3. Academic achievement is a significant predictor of the intentions to pursue postgraduate study.

Hypothesis 4. Awareness about postgraduate study has a mediating role in the relationship between academic achievement and intention to pursue postgraduate study

\section{Method}

In this study, the mediating role of awareness about PG study in the relationship between academic achievement and PG study intentions was examined. Structural equation modeling (SEM) was used to examine the relationships between these variables. The population of the study consists of students of all classes at various departments of the Faculty of Education of Kahramanmaraş Sutcu İmam University 
in the 2018-2019 academic year. Accordingly, a total of 415 students, 255 (.61.44\%) female and $160(38.56 \%)$ male, constituted the sample of the study. When the information about the participants was examined; $96(23.13 \%)$ of the students were in the first year, $94(22.65 \%)$ were in the second year, $108(26.02 \%)$ were in the third year and $109(26.26 \%)$ were in the fourth year.

Personal Information Questionnaire: A personal information questionnaire developed by the researcher (author) included questions regarding the participants' gender, age and years of study in their university.

Awareness about PG Study Scale. Participants' level of awareness of PG study options (Master's programs, or doctorate), the importance of PG study for career and professional development) was assessed using six items developed by the author adapted from previous research and theoretical studies on postgraduate research (Artess and Hooley, 2017; Higher Education Council, 2016; Karakütük, 2002; Lent et al., 1994; Wisker, 2007). Some sample items included: "I am aware of postgraduate studies as a way to get important help in career planning decisions", "I am aware of where and how to find information about postgraduate options". The Cronbach's alpha reliability was .88 .

PG Study Intention Scale. Participants' intentions to pursue PG study were measured using six items adapted from previous research and literature studies (Jepsen and Neumann, 2010; Neumann, 2003; Ling-Yi, 2006; Ünal and İlter, 2010). The items included the students' decisions to engage in PG study, the reasons for their aspirations or intentions to pursue postgraduate study (e.g., becoming an academic, gaining the enriching experiences of higher education, develop professional development), and whether they will be preliminary to meet the requirements of PG study options such as those of a Master's program or a doctorate. Some of the sample items are as following: "I intend studying a $\mathrm{PhD}$ or doctorate program after completing my Master degree", "I wish to undertake postgraduate study in order to become a postgraduate research student after completing my undergraduate degree", "I want to have a professional experience via postgraduate study that would serve my career." The Cronbach's alpha reliability was .81. A five-point Likert scale with $1=$ Strongly Disagree to $5=$ Strongly Agree was used for all instruments.

\section{Data Analysis}

For the analysis of data, SPSS 22.0 and AMOS 22.0 were used. Pearson correlation coefficient was used for the relationship between variables. Before analyses, the data set of normality assumptions were tested using skewness, and kurtosis values $(<|1.96|)$ suggested meeting the criteria for normality assumptions. While the academic achievement variable was an implicit variable, the awareness about PG study options variable was the predictor observed in the structural equation modeling. The PG study intentions as the predicted variable were included in the model as an implicit variable. The mediator role of awareness about PG study in the relationship between academic achievement and intention about PG study variables 
was tested with path analysis. The fit indexes were used to assess the data fit as following: chi square $\left(\chi^{2}\right)$, RMSEA, and fit indices, CFI, IFI, GFI, and, NFI. For each of these fit indices, values greater than .95 show very good fits. In addition, SRMR values $\leq .05$ and RMSEA values $\leq .08$, and, a non-significant $\chi^{2}(\mathrm{p}>.05)$, and $\chi^{2}$ ratio below the suggested 2:1 ratio indicate acceptable model fit (Kline, 2015).

\section{Results}

Correlation analysis results showed that there was a positive correlation between the awareness about PG study and academic achievement $(\mathrm{r}=.21 ; \mathrm{p}<.05)$. In addition, a positive relationship was found between the awareness about PG study and the intentions to pursue PG study $(r=.39 ; \mathrm{p}<.001)$. Finally, a positive relationship between academic achievement and intention to PG study was found $(r=.36 ; p<.001)$. Direct and indirect effects between variables within the scope of this study were tested by SEM. The significance of indirect effect in mediation test was tested by using bootstrapping process (Hayes, 2013). The mediating variable awareness about postgraduate education directly predicted the intention of postgraduate education $(\beta=$ $.45, \mathrm{p}<.001)$. It was also found that academic achievement directly predicted awareness about PG study $(\beta=.17, \mathrm{p}<.001)$. The results of SEM analysis showed that academic achievement predicted the intention of postgraduate education both directly and indirectly $(\beta=.10, \mathrm{p}<.05)$. According to this finding, awareness about PG study played a partial mediating role in the relationship between academic achievement and PG study intention. After this step, the bootstrapping method was used to determine whether the change in the effect of academic achievement variable on the PG study intention was statistically significant. The results of bootstrapping analysis showed that academic achievement had an indirect effect on the PG study intention through the awareness about PG study and this effect was significant. When the analyzes were examined, it was found that academic achievement and awareness about PG study together explained $40 \%$ of the total variance the PG study intentions.

\section{Discussion and Conclusions}

In this study, the mediation role of the awareness about PG study about the relationship between academic achievement and intentions to pursue PG study. was investigated among current undergraduate students. The results of SEM analysis showed that academic achievement directly predicted students' intentions to postgraduate study. Academic achievement which is perceived as consistent with previous research was found to be a significant predictor of attitude towards postgraduate education (Büyükgöze and Gelbal, 2016). Researchers have found that academic achievement and academic motivation levels of university students positively predicted postgraduate education expectations (Pascarella, Cruce, Wolniak and Blaich, 2004; Strayhorn, 2006). Another finding of this study was that the awareness about awareness of PG study positively predicted the intention to continue a PG study. In other words, the awareness of PG study and the importance of postgraduate education for career development was found to be effective in guiding the prospects of university students to pursue PG study. This finding is consistent with 
previous research showing that awareness of postgraduate education played an important role in the career decision of university students. Varhegyi (2009) found that postgraduate awareness for PG study positively influenced university students' career decision and that students' awareness about the relevant PG degree options of undergraduate students were a concept supporting future academic career. The SEM results confirmed are important in terms of revealing that postgraduate awareness mediating the relationship between academic achievement and postgraduate study intentions has an important role in the decision to pursue a PG study. It was found that academic achievement and awareness of PG study affected students' thoughts about continuing to direct the education and career intentions in predicting PG research results yielded awareness and support for the concept of academic achievement. Therefore, the results shed light on many factors shaping the PG study intentions of undergraduate students. First, it is expected that the findings will lead to the undergraduate students and contribute to the postgraduate study intentions. Increasing awareness of PG options seems likely to increase interest and participation in postgraduate studies.

Accordingly, in order to help students become more aware of career planning, universities may consider additional opportunities for undergraduate students from early on. For example, universities can contribute to positively shaping students' future career thinking through regular meetings with postgraduate education, developing and adapting academic career programs for students who are currently in undergraduate degree to better meet the needs of society. Similarly, universities can help to alleviate students' career concerns by providing career counseling centers or academic chambers on campus, providing advice on postgraduate opportunities, career options, and professional expertise. However, it is important to announce this service to all students for participation in postgraduate studies. In addition, public career planning days, graduate information forms on web pages, advertisements related to postgraduate programs, short promotional films are also among the exemplary practices to increase participation in PG study. A monitoring and communication-based mentoring program may also be applied to undergraduate students in order to increase participation in PG study. This can help build a strong image of career awareness in universities. 